\title{
Den Slesvigske Forening I849-1852
}

\author{
Af Jorgen Witte
}

Den Slesvigske Forening var en sammenslutning af antislesvig-holstenske kræefter i Nord- og Mellemslesvig under Treårskrigen. Den arbejdede bl.a. for Slesvigs adskillelse fra Holsten og nøje tilknytning til kongeriet. Foreningens opbygning og virke frem til 1852 skildres her for forste gang $i$ en samlet fremstilling.

\section{Indledning}

Under Treårskrigen opstod der $\mathbf{i}$ Sønderjylland et politisk parti af slesvigere, som var loyale over for forbindelsen med kongeriget. Noget fuldt udbygget parti i moderne forstand var det ikke, som det vil ses af denne artikel, hvor partiets struktur og politik skal skildres. Dette parti, den Slesvigske Forening, fortjener at være hovedemne for en fremstilling; men hidtil har historikere kun omtalt foreningen $i$ andre sammenhænge. Historikeren A. D. Jørgensen, hvis far havde været formand for en filial af foreningen i Gråsten, gav således allerede i slutningen af sidste århundrede en kort oversigt over foreningens virke $i$ bind VI af Danmarks Riges Historie. ${ }^{1}$ I sin skildring af Slesvig Mellem Slagene. En Fremstilling af den civile Kamp om Sønderjylland 1849-50² kom P. Lauridsen mærkeligt nok ikke ind på foreningens virke, men nævnte kun dens eksistens. Da Elisabeth Kardel tre årtier senere skrev sin disputats Die Stadt Flensburg und die politischen und nationalen Zeitströmungen um die Mitte des 19. Jahrhunderts (1929), ${ }^{3}$ kom hun ind på foreningens flensborgske ledelse og hovedforening, men måtte konstatere, at kildematerialet var meget sparsomt. Hun satte den for ovrigt i forbindelse med den kendte nordslesvigske Slesvigske Forening fra 1843, som den ikke har meget andet end navnet til fxlles med. Denne havde standset sin virksomhed i 1848 og genoptog den først igen i 1851, og da begrænset til virke 
for Rødding højskole.4 Få år efter Kardels bog omtalte professor Knud Fabricius foreningens dannelse og noget af dens virksomhed $i$ bind IV af Sønderjyllands Historie fremstillet for det danske Folk, og senest har overarkivar Holger Hjelholt i Sønderjylland under Treårskrigen omtalt forskellige dele af foreningens virke. ${ }^{5}$

Når foreningen er så forholdsvis lidt kendt, kan dette skyldes to forhold, dels at foreningen søgte at skjule en del af sin virksomhed for modstanderne og dermed også for offentligheden, dels at foreningens arkiv syntes at være gået tabt. De ovennævnte forfattere har fortrinsvis bygget på den gråstenske filialforenings arkiv, hvis papirer imidlertid er en blanding af den centrale forenings og den gråstenske filialforenings arkiver. Af centralforeningens protokoller er kopibogen faktisk også blevet bevaret, nemlig under navnet Andreas Christiansens kopibog. Desuden findes materiale fra F. F. Tillischs privatarkiv, Conseilpræsidiets journalsager og artikler i Flensburger Correspondent.

I det følgende skal den historiske baggrund ganske kort ridses op. I marts 1848 nåede den europaiske februarrevolution den danske helstat. Det liberalistiske bourgeoisi i hertugdømmerne gjorde oprør og virkeliggjorde sin idé om en selvstændig stat Slesvig-Holsten. ${ }^{6} \mathrm{Hel}-$ staten var dermed sprængt. I den følgende krig i foråret 1848 havde de danske styrker kortvarigt overtaget, indtil Preussen greb ind til fordel for slesvig-holstenerne, og de tyske tropper endda for en tid trængte op i Nørrejylland. Det var klart, at oprøret ikke kunne nedkæmpes, så længe Preussen støttede slesvig-holstenerne. I vinteren 1848-49 var der våbenstilstand og forgæves forhandlinger om fred, mens en slesvig-holstensksindet fællesregering styrede hertugdømmerne. Danmark genoptog derfor i april 1849 krigen indtil juli 1849, hvor der efter russisk pres etableredes en ny våbenstilstand den 10 . juli 1849. Ifølge denne blev den nordlige del af Slesvig besat af neutrale svensk-norske tropper og den sydlige af preussiske tropper. Demarkationslinjen mellem de to dele gik fra Gelting bugt, syd om Flensborg, nord om Tønder og syd om Rudbøl kog ud til kysten. Hele hertugdømmet skulle administreres i den danske konges navn af en kommission bestående af en dansker, kammerherre F. F. Tillisch, en preusser, viceregeringspræsident Eulenburg, og som mægler englænderen oberst Hodges. Dette styre blev ikke effektivt i Sydslesvig, hvor slesvig-holstenerne udøvede den reelle magt uden synderlige 
indgreb fra de preussiske troppers side. Den tidligere slesvig-holstenske krigsminister Jacobsen kunne således slå sig ned som amtmand i Sørup i Angel og endda søge at udvide sit styre til også at omfatte sognene nord for demarkationslinjen. ${ }^{7}$ Nord for demarkationslinjen fik slesvig-holstenernes modstandere bedre betingelser, bl. a. kunne de landflygtige vende tilbage, og nu dannedes den Slesvigske Forening. Straks efter denne våbenstilstands ophør blev fredsforhandlingerne optaget med Preussen. Under disse kom parterne ikke hinanden meget nærmere, og krigen sluttedes derfor den 2. juli 1850 med en såkaldt »ren og simpel fred «, som udskød afgørelsen af den endelige ordning. Slesvig-holstenerne stod alene og blev slået militært den 25. juli 1850, hvorpå de danske tropper besatte hertugdømmet ned til Danevirke. Hele magten i Slesvig blev nu overdraget Tillisch som overordnet regeringskommissær, og da han fratrådte i marts 1851, overtog han $i$ stedet ledelsen af hertugdømmet som minister for Slesvig. Efter pres fra udlandet måtte han i juli 1851 forlade denne post, der derpå blev overdraget hans svoger Bardenfleth. Et halvt år senere, $i$ januar 1852, faldt også dette ministerium, og den hidtidige ejderpolitik forsvandt med ministeriet Bluhme, der med Carl Moltke som slesvigsk minister agtede at føre helstatspolitik.

Den nationale udvikling, som resulterede i den ovennævnte konflikt, bør også skitseres i denne sammenhæng. Omkring 1800 fandtes der $\mathrm{i}$ hele hertugdømmet en udbredt helstatspatriotisme, centreret om monarken, om monarkiets fælles institutioner, historie m. m. ${ }^{8}$ Byernes overklasse, embedsmændene og deres venner, det velhavende borgerskab, bevægede sig imidlertid bort fra denne patriotisme. Den afløstes hos dem af den moderne nationalisme, som er nøje knyttet til den liberalisme, der fra $1830 \mathrm{i}$ stigende grad vandt indpas i disse kredse. Ligesom byernes økonomiske forbindelser pegede mod syd, mod Hamborg, vendte bourgeoisiets nationalfølelse sig mod syd mod den tyske kultur og det Stortyskland, det håbede ville opstå, og af hvilket Slesvig-Holsten skulle være en del. ${ }^{9}$

Flensborg indtog en særstilling i denne udvikling. Dens økonomiske forbindelser pegede i samme retning som Københavns, og størstedelen af dens købmandsoverklasse, skønt tysksproget, forblev loyal imod den danske helstat. ${ }^{10}$ Hos de lavere klasser $\mathrm{i}$ by og på land fandtes den gamle statspatriotisme stadig. Der var en næsten grænseløs hengivenhed for kongen og en stærk følelse for den danske helstat lige til 
Elben. Spørgsmålet var for dem i 1848 ikke, om de skulle være danske eller tyske, men om de skulle være slesvigere eller slesvig-holstenere, kongetro eller oprorere. I disse loyale lag samledes allerede i slutningen af 1848 talrige underskrifter på adresser rettet mod Slesvigs løsrivelse fra kongeriget og tilknytning til Tyskland."11 Når slesvig-holstenerne så stærkt betonede sammenhængen mellem hertugdømmerne Slesvig og Holsten, måtte disse loyale slesvigere i modsætning hertil gå ind for en skarp adskillelse fra Holsten og nærmere tilknytning til kongeriget.

Tesen bag denne fremstilling er, at den Slesvigske Forening var en sammenslutning af antislesvig-holstenske kræfter af forskellig art blandt slesvigerne. Den spændte vidt fra de nordslesvigske filialforeninger, for hvilke det danske var det væsentlige, over den flenborgske stamforening, som var tysksproget, men stemt for en nær tilknytning til kongeriget, til filialforeningen i Angel, hvis grundlag var lov og orden samt kongetroskaben.

Også socialt var der store forskelle, fra de angelske og sundevedske bønder, over byernes håndværkere til den flensborgske ledelse, som kom fra byens købmandspatriciat.

Det fælles grundlag for disse foreninger var Slesvigs selvstændighed i nær tilknytning til kongeriget og skarp adskillelse fra det Holsten, hvor meget af den tyske slesvig-holstenisme kom fra. Altså en slags ejderpolitik, som måtte glæde regeringen, ministeriet A. W. Moltke, i København. Foreningerne opstod, da de antislesvig-holstenske kræfter ved tremandsbestyrelseskommissionens oprettelse i sommeren 1849 fik forbedrede muligheder $i$ den nordlige halvdel af Slesvig. Efterhånden fik den Slesvigske Forening et betydeligt samarbejde med det danske medlem af kommissionen, Tillisch, som boede $\mathrm{i}$ huset hos foreningens ledende person, storkøbmanden Andreas Christiansen, jr.

Fra sommeren 1850 formindskedes foreningens aktiviteter, og $i$ foråret 1851 var der fare for, at samarbejdet mellem de forskellige filialforeninger under foreningens overdirektion skulle gå helt $\mathrm{i}$ stykker. Årsagerne hertil skal sikkert søges $i$, at nødvendigheden af en privat kamp mod slesvig-holstenerne føltes mindre presserende, efter at Danmark atter besad sine rettigheder $i$ hertugdømmet fuldt ud. Kampen måtte nu i højere grad føres fra administrationens side, og foreningens væsentlige interesse bestod nu i at beholde Tillisch, som den anså som garant for denne udvikling. Efter at han var gået af som slesvigsk 
minister, fik foreningen som politisk parti vel det sidste stod ved helstatspolitikkens genoptagelse med Januarkundgørelsen 1852. Dertil kom foreningens økonomiske svaghed, idet filialforeningerne ikke ville fortsatte med at yde okonomisk stotte til foreningens forbindende og igangsættende organ, overdirektionen.

Foreningens resultater var hverken varige eller store. Dens mål, en fri forfatning for Slesvig i tilknytning til kongeriget, opfyldtes ikke trods et stort arbejde med petitioner og deputationer samt i notabeiforsamlingen. Men for den danske stats ledelse har dens virke sikkert været en væsentlig støtte $i$ den vanskelige tid under Treårskrigen. $O g$ på lokalt plan var tidligere ledende personer i foreningen i mellemkrigstiden frem til 1864 med til at påvirke udviklingen.

\section{Foreningens dannelse}

Den 15. juni 1849 sendtes en dansksproget petition til kongen fra en gruppe på 26 landflygtige slesvigere, som opholdt sig i Sønderborg, der var under dansk militar kontrol. De fremhævede, at selv om de var fordrevne fra hus og hjem, så ønskede de dog ikke våbenstilstand, hvorved, som rygterne lød, den sydlige del af hertugdømmet Slesvig skulle besættes af preusserne, og den danske flådes blokade af Tysklands handel hæves. Dette kunne kun være til gavn for Preussen. Det eneste, disse slesvigere ønskede, var en varig og ærefuld fred. De fleste af underskriverne var flensborgere, og en trediedel var købmænd. Af dem skulle man senere finde købmand og deputeret borger P. A. Petersen, skibsfører Hans Bladt og købmand Andreas Christiansen i ledelsen af den Slesvigske Forening. ${ }^{1}$ Samme Andreas Christiansen, Flensborgs rigeste kobmand, var i denne sidste del af krigskampagnen ansat som ordonnansofficer, som løjtnant i generalmajor de Mezas stab, og havde dér sammen med generalen lejlighed til at se og oprøres over det slesvig-holstenske uvæsen. Han synes allerede på Als at have haft den tanke at tage kampen op med slesvig-holstenismen. ${ }^{2}$

Det kom alligevel til en sådan våbenstilstand, og den 27 . august 1849 drog de preussiske tropper sydpå ud af Flensborg, da de svenske tropper skulle overtage ansvaret for ro og orden. ${ }^{3}$ Situationen lysnede noget for Flensborgs landflygtige modstandere af slesvig-holstenismen, og ud over de ovennævnte vendte også andre, såsom hjulmager Kruse, advokat Blaunfeldt og stenhuggermester Klewing, som var 
kendte dansksindede slesvigere, tilbage til byen. ${ }^{4}$ Der forekom visse voldsomheder den 27. august mellem dansk- og tysksindede; men derpå var det slesvig-holstenske herredømme $\mathrm{i}$ byen brudt. ${ }^{\mathrm{s}}$

Allerede dagen efter, den 28. august 1849, dannedes en Schleswigscher Verein i Flensborg. På dette forste møde valgtes fem direktører for foreningen. Det blev købmand Andreas Christiansen, købmand P. A. Petersen, købmand F. N. Friedrichsen, købmand C. P. Kruse og farver Hans Jensen, som alle var kendt for deres sympati for Slesvigs forbindelse med kongeriget. ${ }^{6}$ Sandsynligvis fastsattes allerede på dette møde, at grundlaget for foreningens virke skulle være kongens proklamation til slesvigerne mere end et år tidligere, få dage efter det slesvig-holstenske oprørs udbrud. I proklamationen af 27. marts 1848 erklærede kongen, at den forfatningsmæssige enhed, en fri forfatning for hele folket, havde måttet opgives på grund af februarrevolutionen. Slesvigerne havde han tilsagt og tilsagde nu igen, at de $\mathrm{i}$ forening med kongeriget og med deres egen medvirken skulle få en fri, folkelig forfatning. Deres selvstændighed som slesvigere skulle ved siden af den fælles forfatning sikres ved en egen landdag, administration, domstole, ligelig andel $\mathrm{i}$ statsafgifterne $\mathrm{i}$ forhold til folkemængde, retfærdig anvendelse af statsindtægternes overskud, ingen consumtion, samt ligeberettigelse af det danske og det tyske sprog på rigsforsamlingen og landdagen. Kongens proklamation opfordrede til sidst slesvigerne til ikke at fornægte deres nedarvede troskab mod kongen og forspilde deres selvstændighed og velfærd.? Dette tilbud om en fri forfatning sammen med kongeriget på betingelse af, at slesvigerne tog afstand fra det slesvig-holstenske oprør, blev basis for den Slesvigske Forening. Dens bestrxbelser måtte gå ud på at vise, at slesvigerne tog afstand fra oproret.

Der var fra foreningens start betydelig interesse for den $\mathrm{i}$ byens befolkning, og mere end 300 mænd sluttede sig til den. ${ }^{8} \mathrm{P}^{\circ}$ et nyt møde $i$ foreningen den 3 . september valgtes endnu et organ til ledelse af foreningen, nemlig et ti-mandsudvalg. Det kom til at bestå af købmand agent $\mathrm{H}$. C. Jensen, krovært Peter Jordt, hårdugsfabrikant Johann Michael Neuffert, lægen dr. Arnold Levestamm, kollektør og krovært Peter Christian Fessel, broskriver Christian Hansen jr., købmand Erich Hansen, købmand Christian Sibbern Sibbers, købmand Carl Wilhelm Overbeck samt ejendomsmægler H. F. Struckmann.'

Blandt de sager, som foreningen straks gik i gang med, var erhver- 
velsen af korporationsret og eget blad. Opnåelsen heraf ville styrke partiet meget. Direktionen indgav en ansøgning til den ny bestyrelseskommission om tildeling af korporationsret til foreningen, men fik afslag på ansøgningen den 19 . september. ${ }^{10}$ Korporationsretten ville have gjort foreningen til en juridisk person og især $i$ formuesforhold have stillet den stærkere. ${ }^{11}$

Denne afgørelse har 'Tillisch sikkert billiget. Ganske vist boede han i Andreas Christiansens hus, kom sammen med ham og kunne ikke være i tvivl om den Slesvigske Forenings hensigt: at befordre og vedligeholde dansk sindelag, anerkendelse af kongen af Danmarks herredømme og rettigheder o. s. v. ${ }^{12}$ Tillischs egen opfattelse ses i øvrigt tydeligt af et brev, han allerede den 15 . august havde skrevet til konseilspresident A. W. Moltke. Heri bad han om tilsendelse af adresser, specielt én fra Flensborg, som udtalte, at man ikke ønskede at skilles fra Danmark, og at man frabad sig andet end det danske flag. ${ }^{13}$ Men når Tillisch sikkert har billiget den nævnte afgørelse, hænger det sammen med, at han på grund af det vanskelige samarbejde $\mathrm{i}$ bestyrelseskommissionen $\mathrm{i}$ den forste tid måtte holde sig uafhængig af partierne. Det var hans agt at vise sin danske tænkemåde ved sine handlinger, ikke ved at knytte sig til bestemte partimænd, udtalte han over for statsrådet. ${ }^{14}$ Hans forbindelser med det loyale parti, den Slesvigske Forening, måtte derfor foregå i det skjulte.

I sin landflygtighed på Als havde Andreas Christiansen talt med general de Meza om nødvendigheden af et såkaldt "modsigelsesblad «, der på tysk kunne tage kampen op med de slesvig-holstenske blades »logne«. Denne plan tog den nydannede Slesvigske Forening straks op, idet et sådant blad ville være velegnet til at udbrede og bekræfte det danske sindelag samt styrke partiet. Christiansen bad nu sin tidligere foresatte om hos konseilspræsidenten at virke for, at et sådant bladforetagende, hvis redaktør udvalgsmedlemmet dr. Levestamm passende kunne være, fik tildelt nogle penge. Der kom imidlertid til at gå en måned, før sagen om bladet, hvis navn skulle være Schleswigsches Echo, blev sendt fra konseilspræsidenten til Tillisch, ${ }^{15}$ og da havde bestyrelseskommissionen allerede taget stilling til foreningens officielle ansøgning. Efter udførligt at have præsenteret det kommende program for bladet anmodede foreningen kommissionen om at tildele det eksklusivret til regeringens bekendtgørelser. Den 19. september svarede bestyrelseskommissionens første departement noget 


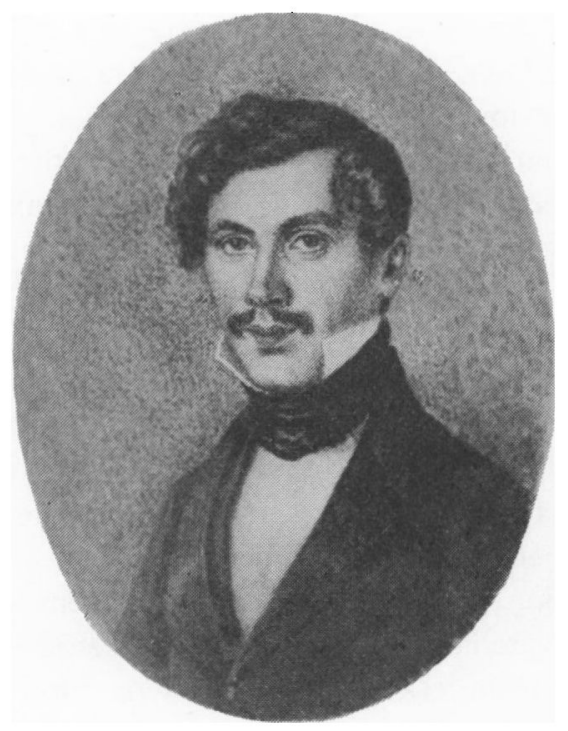

Den ledende direktor $i$ den Slesvigske Forening, den flensborgske storkøbmand Andreas Christiansen junior (1816-1900). Han bavde ikke indtaget nogen fremtredende plads $i$ det politiske liv for Trearskrigen, og efter foreningens oplosning 1852 belligede ban sig atter driften af det gamle familiefirma, til det gik fallit $i$ 1857. I 1864 flyttede han til København. (Det kongelige Bibliotek).

henholdende, at de bekendtgørelser, der egnede sig for bladet, ikke ville blive det nxgtet, såfremt bladet kom til at svare til bestyrelseskommissionens forventninger. ${ }^{16}$ Dette svar fulgte linjen i myndighedernes pressepolitik fra før 1848, aldrig at give et blad en forestilling, for det havde bevist, at det var værdigt til myndighedernes tillid, og var derfor ikke overraskende. ${ }^{17}$ Men den Slesvigske Forening var ikke tilfreds med dette spinkle lofte og opgav derfor denne plan. I stedet anmodedes kommissionen om et trykkeriprivilegium til trykning af et blad i Flensborg. ${ }^{18}$ Svaret kendes ikke; men det har sikkert været et afslag. Løsningen på dette problem kom ad anden vej.

Når foreningens overdirektion hurtigt opgav sin oprindelige plan om et blad, skyldes dette sikkert viden om, at A. S. Kastrup, der havde udgivet og trykt Flensburger Zeitung fra 1840 til 1848, igen ønskede at udgive et blad $i$ byen. Hans gamle ven og advokat $M$. Blaunfeldt ansøgte via fiansministeren grev Sponneck bestyrelseskommissionen om at måtte redigere et dansk-tysksproget loyalt blad i 
Flensborg. Både Sponneck og flere andre ministre syntes, at det måtte være behageligt for bestyrelseskommissionen at have et upartisk - forstået som loyalt - organ til sin rådighed. Blaunfeldt havde ikke bedt om egentlig okonomisk støtte; men finansministeren var $\mathrm{i}$ øvrigt villig til at yde ham pekuniær hjælp i denne sag. ${ }^{19}$ Tillisch, der vel kendte Blaunfeldts ikke uplettede rygte fra 1840'erne, foretrak åbenbart dr. Levestamm, eventuelt dr. Claus Manicus. ${ }^{20}$ Tilsidst fik Sponneck sin vilje, det blev bogtrykker Kastrup, som kom til at udgive Flensburger Correspondent, der redigeredes af Blaunfeldt, og åbenbart med økonomisk støtte fra finansministeriet i København. ${ }^{21}$ At dømme efter dr. Levestamms udtalelser $i$ en ansøgning fem år senere, havde også Tillisch tænkt sig, at der skulle statsstøtte til et bladforetagende med dr. Levestamm i spidsen. ${ }^{22}$

Selv om det ikke blev et fremtredende medlem af den Slesvigske Forening, der blev redaktør af det ny blad, betød dette ingenlunde, at der ikke var forbindelse mellem bladet og foreningen. Som bagmand ved indretningen af bladets hurtigpresse virkede nemlig Andreas Christiansen. Det var ham, der allerede den 27. september bestilte hurtigpressen i København og i Hamborg de ny typer dertil, - i øvrigt svarende til dem, der tidligere anvendtes af Flensburger Zeitung. Han skyndede på leveringen af maskinen og sorgede for betalingen af den; det var dog finansministeriet, der $\mathrm{i}$ sidste instans stod bag. ${ }^{23}$

Flensburger Correspondent viste fra første nummer, at det var modstander af det slesvig-holstenske oprør, og at det opfattede sig som talerør for den loyale befolkning: "Schleswigs gutgesinnte $\mathrm{Be}-$ völkerung «. Bladets program kom i dets tredie nummer. Bladets formål skulle være samlingen af de forskellige antislesvig-holstenske synspunkter $\mathrm{i}$ hertugdømmet, og det måtte derfor tale til de forskellige partier, som fandtes dels i Syd- dels i Nordslesvig, og altså både på tysk og på dansk. Det var en holdning, som både Tillisch og den Slesvigske Forening kunne gå ind for. ${ }^{24}$ I praksis kom det dog til at knibe med det dansksprogede, der udgjorde en stadig mindre del af bladets stof. Vel var bladet loyalt indstillet; men ukritisk overfor bestyrelseskommissionen var det ikke.

Politisk set var Flensburger Correspondent den Slesvigske Forenings organ; men det var ikke ukritisk overfor foreningen. Det kritiserede således $i$ juni 1850 foreningens statutter for at afskære en 
bredere diskussion inden for foreningen. Bladet aftrykte mange af foreningens adresser og andre henvendelser $i$ deres helhed, hvad der viser tilknytning til foreningen. $\mathrm{Da}$ bladet $\mathrm{i}$ efteråret 1850 vendte tilbage til sit gamle navn fra 1840'erne, Flensburger Zeitung, blev dets ny redaktør dr. Claus Manicus, som i foråret 1851 valgtes til foreningens overdirektion. ${ }^{25}$ Både Dannevirke i Haderslev og Freia i Åbenrå åbnede deres spalter for den Slesvigske Forenings synspunkter, da deres redaktører var medlemmer af foreningens filial i disse byer; men pladsen som den Slesvigske Forenings organ tilkom Flensburger Correspondent.

\section{Fallesforeningen og statutterne}

Som parti ville den Slesvigske Forening i Flensborg ikke kunne udrette meget alene. Den måtte etablere forbindelser til andre antislesvig-holstenske kræfter, først og fremmest de dansksindede $i$ Åbenrå og Haderslev. I Åbenrå havde de dansksindede allerede $\mathrm{i}$ november 1848 dannet en forening, Frederiksklubben. Den opstod som en reaktion på hjemmetyskernes bestræbelser for at udrydde danskheden $\mathrm{i}$ politisk og national henseende. Foreningens vedtrgter var ganske enkle, og $\mathrm{i}$ begyndelsen var foreningen vel fortrinsvis et selskabeligt samlingssted for dansksindede borgere og beboere $i$ Ảbenrå og omegn. Efter at foreningens ledelse, vært og flere andre i marts 1849 var fordrevet fra byen af slesvig-holstenerne, vovede de øvrige medlemmer af klubben ikke at røre på sig. Men tiden forandrede også her situationen til det bedre under bestyrelseskommissionen og de svenske troppers besættelse af Nordslesvig. De bortrejste og flygtede dansksindede vendte tilbage til Åbenrå, og klubben samledes igen. $\mathrm{Nu}$ havde medlemmerne andet og mere at varetage end blot at samles til adspredelser. I september-oktober 1849 samledes ca. 140 medlemmer i klubben, og tilvæksten af medlemmer fortsatte. Klubbens sekretær, Frederik Fischer, hævdede ganske vist senere i sin historiske indledning til klubbens første protokol, at foreningen altid havde opretholdt sin upolitiske karakter, og at det store antal adresser, petitioner og erklæringer, hvormed de dansksindede borgere havde grebet ind $\mathrm{i}$ politikken, ikke skyldtes foreningen som sådan, men at de dansksindede borgere, som var aktive $\mathrm{i}$ dette arbejde, kendte hinanden fra foreningen. Denne påstand er ikke rigtig, da 
Frederiksklubbens ledelse $\mathrm{i}$ foreningens navn greb ind $\mathrm{i}$ datidens politik. ${ }^{1}$

Forbindelsen mellem den Slesvigske Forening i Flensborg og de dansksindede i Åbenrå eksisterede allerede i september 1849. Frederik Fischer arbejdede da på at rundsende en dansksproget petition i Åbenrå rettet til bestyrelseskommissionen. Andreas Christiansen skrev til ham og udtrykte håb om, at også landdistrikterne måtte formås til at deltage i petitionen. Han lovede Fischer at sende eksemplarer af proklamationen af 27. marts 1848 forsynet med kongens portræt og nye henvendelser til slesvigerne, så snart de var trykt. Desuden udtrykte Christiansen et stærkt ønske om, at man ville danne en Slesvigsk Forening i Nordslesvig; men nordslesvigerne forstod åbenbart ikke rigtig sagen endnu at dømme efter, hvor lidt man hørte fra dem. ${ }^{2}$

Senere på måneden tog Andreas Christiansen også skridt til et nærmere samarbejde med de kendte dansksindede ledere i Haderslev. Her var der nemlig også dannet en forening af dansksindede. ${ }^{3}$ Denne forening må efter alt at dømme være Harmonien, der var dannet den 27. september 1849, og som ved et møde den 13. oktober med deltagelse af 52 danske borgere fik sine love. Det var en selskabelig forening som en foregående af samme nawn; men det afgørende nye var, at den satte sig for »at befæste den loyale danske ånd «, som Koch sagde i 1852. I øvrigt stod den i et modsætningsforhold til den slesvig-holstenske klub $»$ Die Union ${ }^{4}{ }^{4}$

Christiansen havde kontakt med haderslevske personligheder som pastor Helweg, pastor Hertel, tingmand J. A. Schmidt, Laurids Skau, P. C. Koch og dr. phil. Emil Manicus. Disse fremsatte i slutningen af oktober 1849 et forslag til formålsparagraf for en fælles Slesvigsk Forening og nogle bestemmelser om financiering af en sådan. Det kunne måske have varet nogen tid, før dette nærmere samarbejde var kommet istand, hvis ikke den flensborgske ledelse i en skrivelse den 27. oktober 1849 havde krævet, at det skulle ske allerede i begyndelsen af november. Samarbejdet skulle formaliseres i statutter for den fælles forening, og $\mathrm{i}$ begrundelsen for indkaldelsen til et møde i november henviste ledelsen i Flensborg til, at de flensborgske lokalstatutter var afhængige af godkendelsen af de fremtidige almene statutter for fællesforeningen. Da direktion og udvalg i Flensborg havde godkendt de flensborgske lokalstatutter, som skulle vedtages 
endeligt på en generalforsamling den 6. november, måtte der nødvendigvis holdes et fællesmøde med de ledende personer fra $\mathrm{Ha}$ derslev og Ảbenrå før dette tidspunkt. Sagen ville kunne afgøres endeligt ved et sådant møde - $\mathrm{i}$ stedet for ved lange brevskriverier og de implicerede personer kunne lære hinanden bedre at kende ved mødet, der for ikke at vække opsigt helst skulle holdes $i$ et afsides liggende værtshus, skrev Christiansen til herrerne i Haderslev. Han tilføjede, at det ville være den flensborgske direktion kært, om de ville tale dansk i stedet for tysk. ${ }^{5}$

Mødet fandt sted i Nørby kro i Løjt sogn, lidt nord for Ảbenrå, den 4. november 1849. Deltagerne i sammenkomsten var fra Flensborg næsten hele direktionen, nemlig Hans Jensen, Andreas Christiansen, C. P. Kruse og F. N. Friedrichsen. Fra Ảbenrå kom de ledende fra Frederiksklubben, farver M. Bahnsen, dr. Grauer, kaptajn C. C. Fischer, sukkerkoger og bykasserer A. Andresen, købmand C. T. Guldager samt redaktør Frederik Fischer, mens Haderslev sendte dr. Dessauer, dr. phil. Emil Manicus, redakter P. C. Koch og Laurids Skau.

Den flensborgske direktion havde udarbejdet et foreløbigt forslag til statutter. Med undtagelse af fire paragraffer accepteredes dette forslag, som det forelå. Ændringerne vedrørte formålsparagraffen, ledelsen af fællesforeningen, optagelsen af medlemmer i filialforeninger og sluttelig en bemærkning om, at overdirektionens formand havde den almene ledelse af foreningen. ${ }^{6}$ Dermed forenedes de tre foreninger til et politisk hele, et parti under navnet den Slesvigske Forening. Den skulle fremme Slesvigs vel, dels beskytte Nordslesvig med dets danske særpræg, dels bringe det oprørske Sydslesvig på den rette bane igen. ${ }^{7}$

Formålsparagraffen blev endeligt formuleret på dette møde. Den bestemte, at det almindelige formål skulle vare at virke for hertugdømmets almindelige vel. Udgangspunktet for foreningens virksomhed til den ende skulle være den kongelige proklamation af 27 . marts 1848. Mere specielt fastsloges det, at så længe våbenstilstanden varede, skulle det være foreningens opgave at understøtte bestyrelseskommissionen $\mathrm{i}$ gennemførelsen af lovlig orden og ro og at henlede dens opmærksomhed på alt, som hæmmede denne. Desuden var formålet at gøre fordelene ved den kongelige proklamation klart for folk, altså at propagandere for den. I overensstemmelse med prokla- 
mationens ord om ligestillingen af det danske og det tyske sprog på rigsforsamling og landdag, fastslog den Slesvigske Forenings statutter straks i $\ 2$, at det danske og tyske sprog var ligeberettigede i foreningen - sikkert for at undgå, at dette skulle blive et problem for foreningen.

Den fælles Slesvigske Forening skulle ledes af en overdirektion med sæde i Flensborg, og skulle indtil den første generalforsamling, som påtrenktes afholdt $\mathrm{i}$ oktober 1850 , bestå af den flensborgske direktions medlemmer. Denne bestemmelse til gunst for den flensborgske stamforening, som den kaldtes, indsattes også under mødet $\mathrm{i}$ Nørby kro. Overdirektionens formand skulle have den almindelige ledelse af alle foreninger. Ledelsen skulle foregå ved korrespondence med samtlige filialforeningers direktioner. Når det gjaldt nyheder, meddelelser og indhentning af betænkninger, kunne formanden handle på egen hånd; men så snart foreningens meninger eller onsker skulle udtales, skulle overdirektionen sxtte sig i forbindelse med filialforeningernes direktioner og derefter udtale, hvad der var opfattelsen hos flertallet af direktionerne. Til afholdelsen af udgifterne vedrørende foreningens almindelige formål skulle der etableres en hovedkasse med bidrag fra alle foreningens medlemmer. Denne kasse vil blive omtalt senere $i$ afsnittet om foreningens økonomi.

På mødet i Nørby kro bestemtes det også, at optagelsen af nye foreningsmedlemmer skulle overlades den enkelte filialforening; her havde flensborgerne intet at skulle have sagt. Ved optagelse underskrev den enkelte direktion på den optagnes eksemplar af statutterne, og naturligvis opførtes hans navn også i filialforeningens protokol. Filialforeningerne skulle dog straks ved oprettelsen melde medlemmernes antal, deres navn og bopæl, samt senere ændringer heri, til overdirektionen. Medlemmerne fra alle filialforeninger skulle være ligeberettigede og kunne mod at forevise deres eksemplar af statutterne eller anden legitimation deltage $i$ en anden filialforenings forhandlinger, dog uden stemmeret. Intet medlem måtte offentliggøre foreningens forhandlinger eller beslutninger, dertil krævedes foreningens beslutning.

Den ordinære årlige generalforsamling skulle finde sted i Flensborg, og på denne kunne statutterne xndres efter forslag fra de enkelte filialforeninger. Formålsparagraffen var dog undtaget herfra. Ekstraordinære generalforsamlinger kunne indkaldes, når overdirektionen 
eller filialforeningernes direktioner anså det for fornødent, og et flertal af direktioner kunne kræve en sådan generalforsamling indkaldt. Andragendet derom måtte indleveres 4 uger før afholdelsen af forsamlingen, og indbydelse dertil annonceres $\mathrm{i}$ de dertil passende blade og så betimeligt, at direktionerne mindst 8 dage tidligere havde fået kendskab dertil. Efter at emnet var blevet belyst tilstrækkeligt i diskussion, bestemte præsidenten afstemningsmåden, og ved stemmelighed gjorde hans stemme udslaget.

Bestemmelserne $\mathrm{i}$ disse statutter viser, at hovedindflydelsen på den Slesvigske Forenings politik lå hos overdirektionens formand, den korresponderende direktør Andreas Christiansen, mens filialforeningernes direktioner mere havde en kontrollerende rolle. I nogen grad havde foreningen karakter af et hemmeligt selskab, f. eks. i A benrå og Haderslev med ballotering ved optagelse af nye medlemmer, hvad der sikkert skyldtes krigen og den meget skarpe konflikt med slesvigholstenerne. Medlemmer, som efter et andet medlems mening havde opført sig uværdigt, kunne efter forhør hos vedkommende direktion ekskluderes på en generalforsamling. 8

På Nørbymødet enedes deltagerne om, at disse statutter skulle trykkes i 2000 eksemplarer, og at omkostningerne derved skulle dxkkes af en "vis « kilde, og hvis dette ikke var muligt, skulle de ca. 150 rdl., det ville koste, betales af de tre foreninger i fællesskab. ${ }^{9}$ Denne kilde er vel at forstå som statskassen via Tillisch.

Umiddelbart efter Nørby-mødet trådte direktion og udvalg i Flensborg sammen og godkendte de almene statutter, og i Ảbenrå og $\mathrm{Ha}$ derslev blev de vel godkendt $i$ løbet af de næste fjorten dage, for den 22. november 1849 fik Ảbenrå og Haderslevfilialforeningerne tilsendt de almene statutter, som i mellemtiden var blevet trykt på tysk og på dansk hos Kastrup på den hurtigpresse, som Christiansen havde fremskaffer måneden for. Samtidig med tilsendelsen af statutterne bad overdirektionen om at få oplyst antallet af medlemmer $i$ de to foreninger samt de pågxldendes navne. ${ }^{10}$ Der har været ca. 50 medlemmer i Haderslev, 140 i Ảbenrå foruden de mere end 300 i Flensborg. ${ }^{11}$ De almene statutter gav dog ikke et fuldstændigt billede af foreningens struktur, da det i $\$ 13$ hed, at det stod enhver filialforening frit at tilføje specielle statutter, såfremt de ikke stred mod bestemmelserne $\mathrm{i}$ de almene. ${ }^{12}$ Det er allerede ovenfor næunt, at de flensborgske lokalstatutter var under udarbejdelse i slutningen af ok- 
tober 1849. I indledningen til disse specialstatutter hævdedes, at den flensborgske Slesvigske Forening ifølge $\int 3$ i de almene statutter var stamforening for hele foreningen. Der er ikke tale om noget sådant $\mathrm{i}$ den pågxldende paragraf, kun at overdirektionen havde sit sæde $\mathrm{i}$ Flensborg, og at den til oktober 1850 skulle bestå af den flensborgske direktion. Men påstanden viser vel, at den flensborgske forening var klar over sin indflydelse og var stolt af den. I specialstatutterne fastsattes, hvordan valget af de fem direktører og de ti udvalgsmedlemmer skulle foregå ved, at to direktører og fire udvalgsmedlemmer årligt trådte tilbage, nemlig de, der ved det foregående valg havde fåt færrest stemmer. Efter valg af 6 ny repræsentanter, mødtes de ny med de øvrige medlemmer af udvalget for at vælge to direktører af deres midte.

Det var udvalget alene, som repræsenterede den flensborgske stamforening; men det var direktionen, og især dens formand, som havde initiativet og indflydelsen. For at være beslutningsdygtigt skulle mindst 6 udvalgsmedlemmer være til stede. Både til disse møder og til generalforsamlinger, som en trediedel af foreningens medlemmer og flertallet af udvalget kunne kræve indkaldt, skulle der foreligge en skriftlig dagsorden. Den ledende direktør havde også i stamforeningen den almene ledelse af foreningen, ekspederede sagerne og opbevarede protokollerne $\mathrm{i}$ sit hus. Når foreningens synspunkt skulle udtrykkes udadtil, skulle udvalget imidlertid indkaldes, og direktionen ekspederede dens opfattelse. Udvalgsmedlemmerne godkendte eller forkastede direktionens forslag og beslutninger. Til udforelse af beslutningerne skulle et bud stå til rådighed for direktionen.

Et nyt medlem blev optaget ved henvendelse til et direktionsmedlem, hvor han fik et eksemplar af statutterne. Hvis han var indforstået med dem, blev han foreslået optaget på et fælles direktions- og udvalgsmøde. Hvis han blev accepteret af flertallet, var ingen afstemning nødvendig, ellers skulle sagen for på næste generalforsamling. ${ }^{13} \mathrm{På}$ en række punkter er der overensstemmelse $\mathrm{i}$ ord og indhold mellem de flensborgske specialstatutter og de almene statutter, hvad der peger i retning af, at det oprindelige forslag til almene statutter var udarbejdet af den flensborgske forening. Denne overensstemmelse gør det $\mathrm{i} ø v r i g t$ muligt at undlade en videre detaljeret gennemgang også af specialstatutterne.

Frederiksklubben beholdt sine enkle vedtxgter bestående af tre 
paragraffer indtil februar 1851. Disse bestemte først, at klubben skulle være en forening af dansksindede borgere og indvånere $i$ Åbenrå og omegn. Dernæst, at kun borgere, deres sønner, med døtre, forlovede, samt embedsmænd kunne optages, samt for det tredie, at optagelsen skulle ske ved ballotering eller $i$ en generalforsamling ved anmeldelse, hvis ingen fordrede ballotering. ${ }^{14}$ Harmonien i Haderslev havde også sine egne love. ${ }^{15}$ Men i filialforeningerne, som blev oprettet og tilsluttet fællesforeningen senerehen, synes man at have overtaget de flensborgske specialstatutter. Det var jo heller ikke helt billigt at få egne specialstatutter trykt. Dette gjaldt f. eks. den gråstenske filialforening, som umiddelbart efter oprettelsen besluttede, at i sager, hvor de almene statutter ikke var tilstrækkelige, ville man rette sig efter de flensborgske lokalstatutter, såfremt de var passende for den gråstenske "lokalitet «. Ved samme lejlighed besluttedes også, at foreningens ledelse skulle mødes én gang månedligt, når månen var fuld, og at der skulle stilles et bud til rådighed for direktionen. Disse to bestemmelser svarede også til de flensborgske lokalstatutter, hvorimod en anden gråstensk beslutning om, at uformuende kunne optages gratis, ikke fandtes $\mathrm{i}$ disse. ${ }^{16}$

\section{Udbredelsen af andre filialforeninger}

Som parti måtte den Slesvigske Forening have en bredere opbakning end de 5-600 medlemmer $i$ de tre østslesvigske byer. Der udfoldedes derfor store bestræbelser for at få oprettet filialforeninger andre steder. I dette afsnit vil disse bestræbelser stort set blive omtalt $\mathrm{i}$ kronologisk rakkefølge.

På vejen hjem fra mødet i Nørby kro lagde Andreas Christiansen vejen over Løjt for at sondere stemningen. Han fandt den ret passiv, idet befolkningen ikke syntes, der var nogen grund til at petitionere. Til passiviteten kom den betydelige sociale kløft mellem gårdmænd og kådnere i Løjt, som bevirkede, at gårdmændene ikke ville skrive under på samme ark af en petition som kådnerne. ${ }^{1}$ Der synes dog at have været en aktiv indstilling hos distriktsskolelæreren i Løjt Kirkeby, den ivrige dansksindede Paul Nissen, hvem Christiansen den 22. november sendte 100 eksemplarer af den danske grundlov og 50 eksemplarer af kongens proklamation, sikkert $i$ den hensigt, at Nissen skulle danne en filialforening i sognet. Dette lykkedes dog 
åbenbart ikke. Hans samtidige bestræbelser i samme retning for at få dannet en filial i Agerskov sogn mislykkedes ligeledes. ${ }^{2}$

En anden, Christiansen havde samtale med på sin hjemrejse fra Norby, var farver M. A. Jürgensen i Gråsten. Han havde allerede måneden for tydeligt lagt sit danske sindelag for dagen, $\mathrm{da}$ han sammen med apoteker Henningsen og andre havde søgt tilladelse hos bestyrelseskommissionen til at måtte hejse Dannebrog på kongens fødselsdag den 6. oktober $1849 . .^{3}$

M. A. Jürgensen indkaldte til et stiftende møde for en ny Slesvigsk

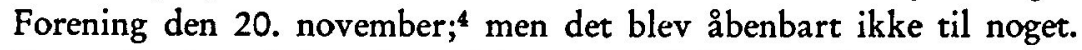
Det trak ud med dannelsen af foreningen. ${ }^{5}$ Grunden kan have været den, at de aktive $\mathrm{i}$ Gråsten og omegn gerne ville have en så stor udbredelse som muligt for foreningen fra begyndelsen. På Jürgensens ønske skrev overdirektionen derfor til mænd som gårdejer Jes Jessen i Vilsbæk, gæstgiver Schmidt i Felsted, pastor Carstensen i Dybbøl og gxstgiver Jørgensen på Broager. ${ }^{\boldsymbol{B}}$ Farver Jürgensen skrev selv til hjulmager Jørgensen i Sottrup for at inddrage ham i arbejdet. ${ }^{7}$ Denne indsats synes at have båret frugt, for filialforeningen for Gråsten og omegn blev efterhånden den starste enkeltforening inden for den Slesvigske Forening.

Den 28. december 1849 konstituerede 66 personer sig i en forsamling i Gråsten som filialforening af den $\mathrm{i}$ Flensborg eksisterende Slesvigske Forening. Til direktionen valgtes énstemmigt som ordfører farver Jürgensen, som kasserer notarius Bojsen og som protokolfører kaptajn Böttcher. ${ }^{8}$ I øvrigt organiseredes foreningens område $\mathrm{i}$ distrikter, hvis formænd fra tid til anden samledes med direktionen. ${ }^{9}$ På det stiftende møde besluttede denne aktive forening at sende statutter og blanketter til bekendte patriotiske mænd i omegnen med opfordring til dem om at samle underskrifter $i$ deres respektive distrikter til foreningen, hvis formål var at bidrage til "landets rolighed og velfærd ", og mere konkret at foranledige en indsamling til understøttelse af »vore sårede danske brødre og de faldnes efterladte ${ }^{.10}$ Desuden beskæftigede foreningen sig med hertugdømmets fremtid, hvordan dets indre og ydre forhold skulle ordnes.

Det var vanskeligere at få sat en forening $i$ gang $i$ Angel end $i$ det overvejende loyalt stemte Sundeved. Slesvig-holstenerne dominerede i de angelske sogne nord for demarkationslinjen; men der fandtes også grupper af loyale eller dansksindede på denne side af Flensborg fjord. 
Den følgende omtale af disse loyales stridigheder med deres slesvigholstensksindede præster i Grumtofte, Stenbjerg og Kværn giver lidt af foruds $x$ tningerne for den angelske filialforening.

I Grumtofte var præsten Georg Carl Wilhelm Schmidt en af de mest fremtrædende slesvig-holstenere - han var således $i$ midten af september 1849 ordfører for en slesvig-holstensk deputation til Berlin. I sine kirkebenner stemplede Schmidt lunkne tilhængere og modstandere af den slesvig-holstenske sag som store syndere. ${ }^{11}$ Isxer hans bøn den 2. september 1849 faldt en mindre gruppe $i$ sognet, hvis repræsentant var sandemand Peter Vollertsen i Dollerup, for brystet. Slesvig-holstenerne kaldte denne gruppe for $»$ Dansch Sinnet Mennesker « eller oprørere. Vollertsen bad den 6. september bestyrelseskommissionen om at afsætte pastor Schmidt. Fra præstens tilhængere i sognet, som åbenbart var de mest fremtrædende mænd, jurater, ottemænd og en regnskabsmand, kom en protest imod Vollertsens klage til bestyrelseskommissionen. De hævdede, at de egentlige fredsforstyrrere var nogle få af de såkaldte dansksindede, som ikke vidste, hvad de selv ville. ${ }^{12}$ Sagen trak ud; men $i$ april 1850 kom en afdeling svensk militær til Grumtofte, hvorpå Schmidt flygtede til Holsten, hvor han døde kort efter. ${ }^{13}$

I nabosognet Kværn ville pastor Desler adlyde amtmanden i Sørup, den tidligere slesvig-holstenske krigsminister Jacobsen, i stedet for den flensborgske amtmand. Tre beboere, Fr. Böttger, Claus Clausen og Peter Petersen klagede $i$ april 1850 over ham til bestyrelseskommissionen. Da kommissionen havde konstitueret den loyale pastor Otzen i Deslers sted, indkom den 27. juni 1850 en takadresse fra sognet, underskrevet af de 12 personer $i$ sognet, som var medlemmer af den angelske filialforening af den Slesvigske Forening. Böttger var direktionsmedlem og Clausen medlem af udvalget $i$ denne filialforening. ${ }^{14}$ Større tilslutning havde de loyale i Kværns østlige nabosogn Stenbjerg, hvor 76 beboere i april 1850 protesterede imod deres præst, pastor Westedt, som også ville adlyde amtmanden i Sørup. Den ledende blandt de loyale i Stenbjerg var åbenbart Jacob Andersen. ${ }^{15}$

I januar 1850 dannedes den angelske filialforening; men allerede $\mathbf{i}$ december 1849 var en gruppe mænd $i$ Østangel blevet enige om at indkalde til en stiftende generalforsamling, så snart et tilstrækkeligt antal mænd havde meldt sig. Foreløbig antog man de flensborgske lokalstatutter. På dette møde var man blevet enige om en længere 


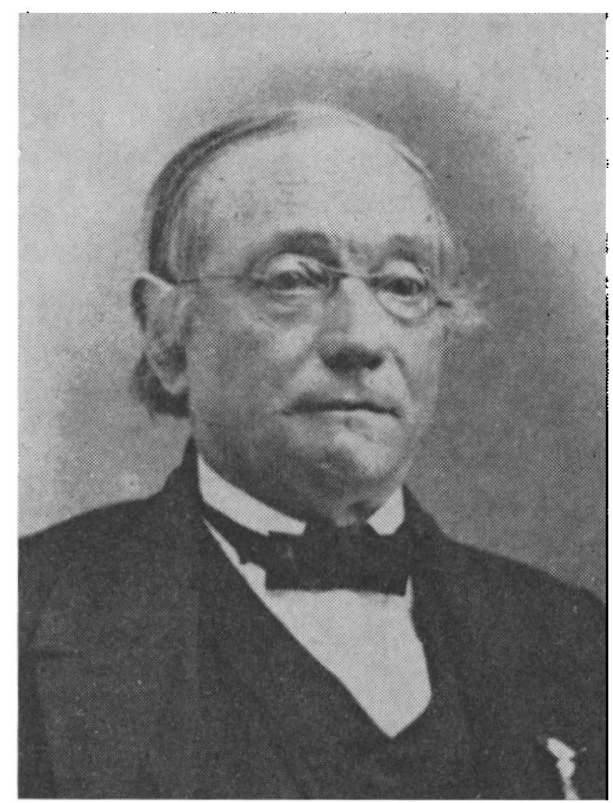

Redakter Fr. Fischer (1809-71), den ledende $i$ det danske arbejde $i$ Abenra. Han var Frederiksklubbens sekreter og farte dens korrespondance med overdirektionen i Flensborg. (Historiske Samlinger for Sonderjylland).

programerklæring. Man konstaterede, at baggrunden for foreningens dannelse var krigstrætheden. Man ville have fred med eget styre, garanti imod fremmed vilkårligt styre og skattebyrder, samt beskyttelse af nationaliteten. Der eksisterede ganske vist i Angel en levende sympati for Tyskland; men dette var kun en fremtidsvision, som aldrig kunne foretrækkes frem for den anerkendte retssætning, at hertugdømmet Slesvig aldrig havde været og aldrig ville blive medlem af Det tyske Forbund undtagen ved erobring. Man ville kæmpe imod "Wühlere ( (urostiftere) af enhver art og ønskede igen at leve $\mathrm{i}$ fordragelighed med kongeriget Danmark, sådan som man havde gjort det $\mathrm{i}$ århundreder. Desuden ville man slutte sig sammen $\mathrm{i}$ en Schleswigscher Verein für Ostangel og der gøre sig til opgave at bistå dem, der på grund af krigen led under invaliditet og af fattigdom. ${ }^{\mathbf{1 6}}$ Denne filialforening anslog dermed fra begyndelsen en mere konservativ tone end den flensborgske forening. 
I december havde udsendinge fra Angel tilbudt overdirektionen at tilslutte sig foreningen. ${ }^{17}$ Det realiseredes den 13. januar 1850 , da 27 angelboer, hvem »det fælles fædrelands vel $\mathrm{i}$ tro, retskaffent sindelag lå på sinde « samledes og dannede Schleswiger Verein in Angel. Direktionen kom til at bestå af pastor Martens i Nykirke, gårdejer Petersen på Niesgrusgård, Fritz Böttger i Hatlund og sandemand Peter Vollertsen. Pastor Martens fra Nykirke, der grænser op både mod Stenbjerg, Kværn og Grumtoft, var en af de få gejstlige, som var forblevet regeringen tro. Der dannedes et udvalg, hvor de distrikter, som foreningen opdeltes $i$, hvert skulle være repræsenteret med to eller tre medlemmer, først Stenbjergområdet, dernæst Gintoft med Nordgårdholt og Habernæs og som det tredie distrikt Grumtofte sogn. Den følgende søndag steg antallet af medlemmer til 160, og der valgtes udvalgsmedlemmer for Sterup, Grønholt og Esgrus distrikter. Foreningens forsigtige og konservative holdning udtryktes nu klarere. Man fandt, at formålsparagraffens tredie del burde udtrykkes mere alment og forsigtigt. Foreningens basis var kongens forhåbning og forventning til alle beboere $\mathrm{i}$ hertugdømmet Slesvig, sådan som det var udtrykt i proklamationen af 27 . august 1849 , altså lov og orden. Det mål, som man ville sætte sig, var at fremme landets vel, dets åndelige og sædelige højnelse ad ordnet lovlig vej. Man skulle vandre en vej $i$ lydighed mod loven, fjernt fra enhver form for politik!18 Det var noget andet end den Slesvigske Forenings krav om en fri, folkelig forfatning.

Også i egnen umiddelbart nord for Flensborg, i Bov sogn, samlede de loyale sig. I januar 1849 havde nxsten 100 beboere dér sendt en adresse til kongen med klager over den slesvig-holstenske Fællesregering. Adressen var på tysk; men underskriverne var meget utilfredse med de stadig flere tysksprogede embedsmænd, skønt befolkningens omgangssprog var dansk. De så deri en støtte til de slesvig-holstenske oprørere. ${ }^{19}$ I foråret 1849 havde de loyale i Bov sogn en strid med deres præst, som var gået så vidt som at lade oplæse ved kirkestævne, at man skulle adlyde den slesvig-holstenske amtmand Jacobsen $\mathrm{i}$ Sørup. 60 mænd bad $i$ en dansksproget adresse bestyrelseskommissionen om at afsætte præsten og erstatte ham med en anden loyalt sindet præst. ${ }^{20}$ Samtidig med denne strid oprettedes mellem den 18. og 26. marts 1850 en filialforening af den Slesvigske Forening i Bov. Den deltog straks aktivt $i$ arbejdet ved at underskrive en protest- 
adresse og måneden efter ved at sende en deltager $i$ en stor deputation til København, nemlig Erich Clausen. Filialforeningens direktion bestod af C. Petersen i Harreslev, skolelærer Johannes Chr. Thomsen i Frøslev, skolelærer Christian Sørensen i Kollund, A. Schmidt i Kollund og A. Sørensen fra Vejbæk. ${ }^{21}$

Måneden efter meldte der sig en anden filialforening i Angel. Den 27. april 1850 havde 22 personer fra Skidenholvej, Svenau, Drej og Holnæs i Munkbrarup sogn fundet sammen $i$ en filialforening, skrev de på dansk til overdirektionen. Dens grundlag var de flensborgske lokalstatutter, og den ville virke $i$ samme ånd. Denne filialforening havde meldt sin oprettelse til foreningen i Østangel, men fandt det under de betrængte forhold i Angel rigtigst at stifte en ny filialforening fremfor at tilslutte sig den eksisterende. ${ }^{22}$ Overdirektionen anmodede som sxdvanlig den ny forening om medlemmernes navne og bopxl, samt spurgte, hvor mange eksemplarer af statutterne, der ønskedes. Overdirektionen tilføjede, at kontingentet til hovedkassen i Flensborg ikke måtte afholde nogen fra at indtræde $i$ foreningen. Hvis de ikke havde råd, kunne de optages gratis, hvis de kvalificerede sig dertil. ${ }^{29}$ Det var åbenbart allerede overdirektionen bekendt, at foreningen i Skovsende, som den kaldtes, overvejende ville komme til at bestå af småkårsfolk. Formand for filialforeningen var derimod landinspektør Sternhagen i Lyksborg. ${ }^{24}$

I maj 1850 fulgte så oprettelsen af to filialforeninger i Aller og Tinglev, om hvilke der kun findes ganske få oplysninger. De synes at være blevet stiftede af en hr. Bröchner. ${ }^{25}$ Han kan være identisk med husfogeden for Rise og Sønder Rangstrup herreder, samt konstitueret i Varnæes birk og Lundtoft herred, Peter Johannes Bröchner, som også senere var medlem af den Slesvigske Forening. ${ }^{26} \mathrm{Da}$ overdirektionen havde modtaget oplysning om dannelsen af filialforeningen i Aller, svarede den den 23. maj 1850, at filialforeningen kunne få statutterne hos direktionen i Haderslev - det var den nærmeste filialforening. I øvrigt ønskede man oplysning om navn og bopxl på medlemmerne. ${ }^{27}$ Kort efter synes lærer og degn i Aller, Mogens Sorensen, der var den ledende $\mathrm{i}$ denne filialforening, at have oplyst, at den talte 16 medlemmer, men at mænd $i$ flere sogne $i$ omegnen af Aller følte trang til at slutte sig til den Slesvigske Forening. Overdirektionen foretrak dog naturligt nok, at der skete en sammenslutning med den eksisterende filial i Aller. ${ }^{28}$ 
Samtidig med oprettelsen af den nordligste filialforening i Aller, dannedes foreningen $i$ Tinglev og Uge sogne, om hvis forhold der dog ikke vides meget. Andreas Christiansen havde allerede i slutningen af november 1849 skrevet til seminarist Schmidt $i$ Tinglev og sendt ham 10 eksemplarer af foreningens almene statutter med onsket om, at han ville danne en filialforening på stedet; men intet var åbenbart kommet ud af det dengang. ${ }^{29} \mathrm{Nu}$ var det krovært Petersen i Tinglev, der var den ledende i filialforeningen. ${ }^{30}$

Derefter kom der en pause i tilvæksten af ny filialforeninger til foreningen. Felsteddistriktet af den gråstenske filialforening etablerede sig ganske vist $i$ efteråret 1850 som en selvstændig filialforening, måske efter en personstrid med den gråstenske direktion; men dette ændrede ikke noget særligt ved den Slesvigske Forenings struktur. ${ }^{\mathbf{1 1}}$ Den sidste filialforening, som tilsluttedes den Slesvigske Forening, kom i sommeren 1851 i Lille Solt. Der havde allerede året før, i juni 1850 , vist sig interesse i Adelby, Rulskov, Hyrup, Oversø samt Lille Solt syd for Flensborg for at danne en filialforening; men overdirektionen havde dengang henvist dem til at slutte sig til foreningen $\mathrm{i}$ Østangel, ${ }^{32}$ nok fordi den ikke ønskede en for stor opsplitning af kræfterne. Efter en petitionskampagne $i$ april 1851, som havde givet godt resultat $\mathrm{i}$ disse egne, bad den ny overdirektion skolelærer $\mathrm{J}$. $\mathrm{O}$. Nissen, en søn af den $i$ indledningen til dette afsnit omtalte Paul Nissen, om at danne en ny filialforening i Lille Solt. Dette synes at være sket kort efter. ${ }^{33}$

Den Slesvigske Forening hævdede imidlertid også at repræsentere de loyale i de egne af hertugdømmet, hvor der ikke var etablerede filialforeninger under den flensborgske overdirektion. Overdirektionen havde kontaktmænd i disse egne, f. eks. pastor Hansen i Fjolde, pastor Christiansen i Medelby, H. A. Krüger i Bevtoft og dr. Levin i Løgumkloster. ${ }^{34}$ Dertil kom et par selvstændige foreninger, som samarbejdede med overdirektionen, men ikke lod sig inddrage $i$ en fastere forbindelse til overdirektionen. I Højer var de dansksindede de slesvig-holstenske talmæssigt overlegne, men vovede alligevel ikke at træde frem. Efter at der dér i oktober 1849 var dannet en Tysk Forening, ville de dansksindede, især apoteker Hermann Nagel, købmand Petersen og dr. Vinding, danne en forening i modsat retning; men de opgav det af frygt for krigens genopblussen. ${ }^{35}$ I forsommeren 1850 dannedes der alligevel en forening, som deltog $i$ en af den 
Slesvigske Forenings adresser. Men apoteker Nagel synes ikke at have svaret på overdirektionens opfordring til at tilslutte sig den Slesvigske Forening. ${ }^{36}$ Der fandtes $i$ øvrigt $i$ det nærliggende Emmerlev en lille dansk forening, stiftet den 19. oktober 1848, hvis formål og aktiviteter svarede ret nøje til den Slesvigske Forening; men nogen sammenhæeng har ikke kunnet spores. ${ }^{37}$

Betydelig mere kontakt havde overdirektionen med den Danske Forening for Als og Sundeved, hvis formand var dr. H. J. Matthiesen i Sønderborg. Denne forening bad i foråret 1850 overdirektionen om den Slesvigske Forenings støtte til en stor adresse rettet imod en slesvig-holstensk deputation, der i Berlin foregav at tale på slesvigernes vegne. Overdirektionen benyttede denne lejlighed til at søge etableret en fastere forbindelse til den Danske Forening, idet den foreslog en samtale mellem de to foreningers direktioner, især med henblik på $\ 1$, altså formålsparagraffen, og på proklamationen af 27. marts 1848. ${ }^{38}$ Dr. Matthiesen har åbenbart gjort Andreas Christiansen opmærksom på, at forskellene mellem de to foreninger var for store, for Christiansen afsluttede sit følgende brev med at skrive, at forskellene gjorde en personlig samtale mellem de to direktioner ønskværdig. ${ }^{39}$ Nogen egentlig sammenslutning kom der vist ikke ud af dette frieri; men senere $\mathrm{i}$ foråret 1851 oplystes det, at der fandtes en aftale (»status«), og $\mathrm{i}$ hvert fald havde den Slesvigske Forening et nøje samarbejde med den Danske Forening for Als og Sundeved, lige så længe foreningens virke kan følges. ${ }^{40}$

\section{Medlemstal og sociale tilhørsforbold}

Det lykkedes den Slesvigske Forening i løbet af vinteren 1849-50 at samle 9011 underskrifter på en adresse til kongen med partiets program; men den egentlige opbakning af foreningen $i$ form af medlemsskab var langt mindre. ${ }^{1}$ Antallet af medlemmer i foreningen kan ikke oplyses nøjagtigt, dels fordi en væsentlig del af foreningens medlemslister er gået tabt, dels fordi ikke alle filialforeninger gav ajourførte oplysninger om deres medlemmer. Fra november 1849 til marts 1850 synes foreningens medlemstal at være vokset fra ca. 500 til ca. $1000 .^{2}$ Fra juni 1850 og maj 1851 findes to samlede opgørelser, som giver et nogenlunde pålideligt indtryk af foreningens størrelse. 
Det skal dog bemærkes, at $\mathrm{da}$ Gråsten filialen ophævede tilknytningen til den Slesvigske Forening i maj 1851, viser disse tal foreningens største omfang.

Haderslev

Ảbenrå

Skovsende

Tinglev

Bov

Flensborg

Gråsten og Felsted

Østangel

Aller

I alt

$$
\text { Juni } 1850^{3}
$$

50

138

75

?

?

392

339

150

16

1160
Maj $1851^{4}$

50

136

108

33

100

412

521

54

Man kan altså konstatere, at foreningen på sit højeste havde ca. 1400 medlemmer, hvortil kom et ukendt antal medlemmer af den Danske Forening for Als og Sundeved. Men tallet når langt fra op på de 2-3000 medlemmer, som Andreas Christiansen oplyste overfor minister H. N. Clausen $\mathrm{i}$ juli 1850 for at få placeret fordelingen af danske bøger $\mathrm{i}$ hertugdømmet $\mathrm{i}$ foreningens hxnder. ${ }^{5} \mathrm{Et}$ forsøg på analyse af svingningerne $i$ de enkelte foreningers medlemstal kan oplysningerne dog næppe bære.

Det er ikke mindre interessant at få konstateret direktionernes og medlemmernes sociale tilhørsforhold. Den flensborgske direktion, som samtidig var overdirektion for hele foreningen, bestod fra august 1849 til maj 1851 af fire købmænd og en farver, mens stamforeningens timandsudvalg bestod af tre købmænd, en ejendomshandler, to fabrikanter, en læge, en broskriver samt to gæstgivere. ${ }^{6}$ Det var tydeligvis Flensborgs ledende sociale og politiske lag, storkøbmændene, som dirigerede den Slesvigske Forening, især igennem direktionen. ${ }^{7}$ I maj 1851 konstituerede den ny overdirektion sig. Den kom til at bestå af en læge og en broskriver, to købmænd og en farver, mens den nyvalgte flensborgske lokalledelse bestod af en fabrikant, en stenhuggermester, en murermester, en hjulmager og en skipper. ${ }^{8}$ Det 
var tydeligvis lavere sociale lag, som nu sad i ledelsen af den Slesvigske Forening. Købmændene havde måske ikke længere brug for den.

Det er uhyre vanskeligt at sige, hvordan den sociale sammensxtning af den flensborgske stamforenings medlemmer var, da der ikke kendes nogen medlemsfortegnelse eller petition, som kan oplyse noget derom. Det eneste fingerpeg er en udateret adresse fra slutningen af 1851 eller begyndelsen af 1852, som er underskrevet af 246 loyale borgere, der andrager om afsættelsen af rådstjenerne Ohlsen og Lohse, som under oproret havde tjent den slesvig-holstenske sag. Da stamforeningen på dette tidspunkt ikke underskrev lokale sager med betegnelsen "Slesvigske Forening ", kan det med rimelighed antages, at aktionen skyldes den lokale Slesvigske Forening. De 62 af underskriverne kunne ikke identificeres tilstrækkeligt sikkert. Af resten var 93 håndværkere m. m., 17 svende og daglejere, 35 gæstgivere, høkere og mindre handlende, og kun 17 købmænd, fabrikanter o. $1 .^{9}$ Svarede underskriverne af petitionen til stamforeningens medlemmer, kan man konkludere, at kernen $\mathrm{i}$ den var den lavere middelstand, hvorimod underklassen kun var svagt repræsenteret. Således var der en klar modsætning mellem sammensætningen af ledelsen og basis $i$ social henseende. Det er måske udfra denne modsætning, at man skal forstå Flensburger Correspondents kritiske bemærkninger om foreningens stramme statutter, der udelukkede større debat $i$ foreningen.10 End ikke oplysning om foreningens formand Andreas Christiansens tre måneders rejse til Sydtyskland og Frankrig i efteråret 1850 synes de menige medlemmer at have fået. ${ }^{11}$

G. Japsen har undersøgt de tilsvarende forhold for Frederiksklubben, som er betydeligt bedre belyst. De ledende dér var farver $M$. Bahnsen, lægen J. Grauer, kaptajn C. C. Fischer, købmand Guldager, boghandler Sørensen, modehandler E. Jacobsen, købmand Johan Nielsen samt især redaktør Fischer. Købmændene spillede ikke den samme betydelige rolle som i Flensborg, da de hér overvejende var slesvig-holstensk sindede. Af de 129 medlemmer, som Frederiksklubben havde i marts 1849, altså mere end et halvt år, før den blev en del af den Slesvigske Forening, var 26 købmænd, 86 håndværkere, 5 intellektuelle og 12 landmænd. Derimod var der ingen fra arbejderklassen, Ả benrås urokkelige danske fundament. ${ }^{12}$ I Haderslev var de ledende $\mathrm{i}$ filialforeningen af den Slesvigske Forening tingmand J. A. Schmidt, købmand de Wolff, lægen dr. Dessauer, konrektor dr. phil. 
Emil Manicus, redaktor Koch og for en kortere tid også pastor Helweg og gårdejer Laurids Skau. Den sociale sammensætning af medlemmerne i Harmonien i Haderslev mindede meget om forholdene $i$ Ảbenrå og Flensborg med en betydelig repræsentation af middelklassen, men så godt som ingen fra underklassen, som også i Haderslev var det faste danske fundament. ${ }^{13}$

Til slut skal der nævnes lidt om forholdene på landet, i Skovsende, Gråsten og Østangel. I Skovsende ved Flensborg fjord bestod direktionen i foråret 1851 af landinspektør Sternhagen i Lyksborg, pastor Jensen samt smed Hartmann i Skovsende, gårdmand og regningsmand Peter Lorenzen i Tarup samt storkådner Franz Hansen i Skovsende. ${ }^{14}$ Medlemmerne var generelt fattige, idet mere end halvdelen bestod af kådnere, arbejdsmænd, daglejere samt nogle håndværkere. ${ }^{15} \mathrm{Kun}$ ca. 20 af foreningens ca. 100 medlemmer kunne betegnes som velstående. ${ }^{16}$ Det var vel dem, der ledede filialforeningen. I Gråsten bestod direktionen af farver Jürgensen som formand, notarius advokat Bojsen som kasserer og kaptajn Böttcher som sekretær. ${ }^{17}$ Sammen med direktionen virkede flere distriktsformænd. Det var oprindelig tingskriver Sørensen fra Broager, gårdejer Peter Jacobsen Lassen, gårdejer Hans Hansen Stensvang og Jes Andersen fra Vilsbæk. ${ }^{18}$ Medlemmerne synes at have været bønder; men en nøjere analyse heraf går ud over undersøgelsens rammer. ${ }^{19}$

Formand for filialforeningen i Angel var først pastor Martens, som ved sin forflyttelse til Åbenrå afløstes af gårdejer Fritz Böttger i Hatlund. Resten af direktionen bestod af gårdejer Henningsen $i$ Grønholt, gårdejer og regningsmand $P$. Lassen i Strukstrup foruden den fraværende pastor Martens. ${ }^{20} \mathrm{Udvalgsmedlemmerne} \mathrm{synes} \mathrm{lige-}$ ledes at have været gårdejere. Kun få af disse repræsentanter var samtidig regningsmænd, jurater, ottemænd 0 . 1., som i stedet synes at have sluttet op om slesvig-holstenismen. Hvordan den sociale sammensætning af de menige medlemmer af filialforeningen i Angel var, sandsynligvis noget forskellig fra den gråstenske, er en opgave, som jeg har måttet opgive at løse.

Medlemsskaren synes altså socialt at have været middelklassen både på landet og $\mathrm{i}$ byerne, d. v. s. bønder og håndværkere. Underklassen var vel repræsenteret, især i Skovsende, men næppe meget. Filialforeningernes direktioner synes stort set socialt at have svaret til medlemsskaren. I så henseende synes Flensborg med overdirektion 
og timandsudvalg at have dannet en undtagelse, der må forklares ud fra byens særegne økonomiske og nationale udvikling.

\section{Foreningens økonomi}

Foreningens statutter bestemte i $\$ 9$, at der af ethvert medlem skulle betales et halvårligt kontingent på $8 \mathrm{~B}$ til bestridelse af de nødvendige almene udgifter. ${ }^{1}$ Denne bestemmelse skulle volde betydelige vanskeligheder, og inden første generalforsamling var foreningens økonomi i håbles uorden.

$\mathrm{Da}$ det første halve år efter sammenslutningen af de tre foreninger i Flensborg, Åbenrå og Haderslev var gået, skulle beløbene indkasseres. Den 8. juli 1850 fik Erich Hansen, der p.t. var kasserer for den flensborgske stamforening, ordre til at begynde indsamlingen af kontingentet i Flensborg. ${ }^{2}$ I august resterede der så meget af det almene kontingent hos filialforeningerne, at overdirektionen begyndte at presse dem. Foreningen for Grăsten og omegn var den eneste, som ikke var i restance for det første halvår. ${ }^{3}$

Overdirektionen anmodede $i$ slutningen af august 1850 Frederiksklubben om indsendelse af restancen for første halvår og om at påbegynde indsamlingen for andet, lige som man allerede gjorde $\mathrm{i}$ Flensborg. ${ }^{4}$ Foreningen i Skovsende havde i maj meddelt overdirektion, at der endnu resterede noget af første halvårs kontingent. Overdirektionen antog, at den sag kunne bringes $i$ orden nu sammen med en oversigt over evt. medlemstilgang. ${ }^{5}$ Dårligere stod det til med foreningen i Angel. Herfra kendte man kun tallet på underskrivere på petitionerne, ikke antallet af medlemmer, og ligeså uvist var det, hvordan det forholdt sig med opkrævningen af det almene kontingent for første halvår. ${ }^{6}$

Vanskeligst forholdt det sig med foreningerne i Haderslev, Tinglev og Aller. Allerede den 6. juli 1850 havde overdirektionen anmodet om at få en oversigt over direktionsmedlemmerne i Haderslev, da man af underskrifterne på en skrivelse havde udledt, at pastor Helweg nu var bestyrelsesmedlem, og indtrængende bad man om indsendelse af kontingentet. ${ }^{7}$ Ả benbart kom der intet positivt svar, for $i$ august tog Andreas Christiansen en ordentlig torn med dem. Foreningerne måtte tage pligterne sammen med rettighederne, og han tvivlede slet ikke på, at kontingentet forlængst var betalt o.s. v. ${ }^{8}$ 
Det gjorde han nu nok, og med rette, for senere kom det frem, at hadersleverne simpelthen var modstandere af kontingent som sådant, og at deres filialforening hele tiden havde arbejdet uden at opkræve noget kontingent. ${ }^{9}$

Der var tidligt problemer med det almene kontingent fra filialforeningen i Aller. Kort efter foreningens oprettelse skrev Christiansen til dens formand, at han ville gøre opmærksom på, at der skulle betales et alment kontingent. ${ }^{10}$ Heri var denne åbenbart ikke enig, for Christiansen replicerede atter skarpt: Ved oprettelsen af den almene Slesvigske Forening var statutterne blevet vedtaget af alle dens medlemmer og kunne derfor kun xndres med alle foreningers billigelse. Havde foreningen i Aller ved sin oprettelse foretaget en xndring i paragraffen om kontingentet, var dette et skridt, som overdirektionen ikke kunne acceptere.«

I efteråret $1850 \mathrm{kom}$ det frem, at når der var vanskeligheder med at få indkrævet det almene kontingent både fra Tinglev og fra Allerfilialerne, skyldtes det, at Bröchner ved deres oprettelse ikke havde forklaret nødvendigheden deraf. Dette var efter overdirektionens mening meget forkert, da trangen til at slutte sig sammen $i$ en forening dengang blev følt så stærk og rigtig, at man ikke ville have undladt det på grund af et ringe kontingent. ${ }^{12}$

Der synes ikke at være kommet noget tilfredsstillende svar i denne sag for Aller, og da forståelsen med den fra overdirektionens side heller ikke var god $i$ en adressesag, ophørte forbindelsen med den efter julen 1850.13 Forbindelsen med filialen i Tinglev fortsatte derimod, og denne deltog også i mødet i Flensborg i marts 1851, hvor foreningen skulle reorganiseres, og efter hvilket overdirektionen besluttede at opgive at kræve Tinglev for det gamle kontingent. ${ }^{14}$

Der var således en ret udbredt modvilje imod det almene kontingent. Dette søgte overdirektionen at modvirke, da pengene skulle opkræves $\mathrm{i}$ august 1850 , ved at foreslå de forskellige direktioner $\mathrm{i}$ filialforeningerne, at omkostninger ved at afsende deputationer etc. ikke skulle afholdes af filialforeningen, men af den almene kasse. ${ }^{15}$ Imod denne idé syntes der især at være gammel modstand i Abenrå og Haderslev. Christiansen skrev til Haderslev, at ganske vist havde disse to foreninger ved oprettelsen udtalt, at rejseomkostningerne for foreningernes deputerede såvel som til fælles forsamlinger skulle afholdes af private midler. Men det var nu indlysende for alle direk- 
tioner, at det var upraktisk, hævdede overdirektionen, sikkert med tanke på den deputation, foreningen havde afsendt til København $\mathrm{i}$ foråret 1850, hvor ikke alle områder i hertugdømmet var repræsenteret. ${ }^{16}$ Dette forseg på at motivere filialforeningerne for betalingen af det almene kontingent mislykkedes, så den almene kasses gæld i marts 1851 var oppe på 408 mark, selv om kassereren var en stor købmand som F. N. Friedrichsen.

Det almene kontingent betaltes nemlig kun én gang og endda ikke af alle. Foreningerne i Åbenrå og Haderslev betalte intet, og Bov efterkom heller ikke kravet herom. Foreningerne i Aller og Tinglev mente sig fritaget for kontingentet, og foreningen i Angel betalte kun en del. Økonomisk kom overdirektionen derfor til at stå yderst svagt, og der kan næppe være tvivl om, at dette har medvirket til at svække dens og hele foreningens handlekraft. ${ }^{17}$

\section{Foreningens politik}

I dette afsnit er det den Slesvigske Forenings almene politik, som skal omtales. De lokale aktioner, som filialforeningerne satte i værk, eksempelvis den flensborgske stamforenings bestræbelser for at få afsat den slesvig-holstenske lærer og degn ved St. Nikolaj, Heinrich Burgwardt, ${ }^{1}$ eller den haderslevske filialforenings klage over det blodige overfald i Haderslev fra slesvig-holstenernes side henimod jul $1849^{2}$ vil derimod ikke blive omtalt, da de $\mathrm{i}$ mindre grad belyser foreningens politik end modsætningsforholdet til de lokale slesvigholstenere.

De midler, hvormed partiet førte sin politik, var især petitioner, adresser og deputationer. Der førtes også en almen politik på en anden og bestemt ikke mindre vigtig front, nemlig ved indsamlinger, men det egner sig dog ikke til belysning af de forskellige synspunkter inden for foreningen og dens forhold til Tillisch og den danske statsledelse. Aktiviteterne på dette felt startede i efteråret $1849 \mathrm{og}$ fortsatte storstedelen af 1850 . Der arrangeredes skillingsindsamlinger $i$ lukkede bøsser, så også de lavere klasser kunne lægge deres skærv, der afholdtes maskerader, indsamledes penge på subskriptionslister, samledes penge ved rejsegilder, foranstaltedes lotterier o. s. v., og efter slaget ved Isted samledes der også tøj ind til de sårede. Det blev til tusinder af rigsbankdalere, som sendtes ind til formanden for Cen- 
tralkomiteen til understøttelse af de sårede og faldnes efterladte, C. A. Meyer i København. ${ }^{3}$ Den Slesvigske Forenings almindelige politik og aktiviteter var kun for mænd; men $i$ en del af disse indsamlinger var det overdirektionens kvindelige slægtninge, der førte an. ${ }^{4}$ Baggrunden for denne magtige aktivitet var dog ikke kun filantropisk. I anledning af et smukt indsamlingsresultat fra Sundeved udtrykte Andreas Christiansen det således over for et par filialforeninger: "På Sundeved har alle, såvel herre som tjener, deltaget ved at yde et bidrag en gang for alle. Dette er en kendsgerning, som mere end nok så mange smukke adresser viser befolkningens sande folelser, og det vil ikke forfejle sit mål, nemlig ud over den tilbørlige understøttelse af dem, der er blevet invaliderede og har mistet deres pårørende for slesvigernes skyld, også at vise folket, hvem der har de fleste slesvigeres virkelige sympati ${ }^{5}{ }^{5} \mathrm{På}$ den måde var indsamlingerne og lignende aktiviteter ganske på linje med partiets store petitions- og adressesager, som også skulle demonstrere styrken af de loyale slesvigeres sympatier.

Den politik, som foreningen førte, måtte naturligvis rette sig efter den til enhver tid givne situation, som skiftede meget under Treårskrigen og den nærmeste tid derefter. Det synes muligt at dele den tid, som foreningen virkede $i, i$ tre perioder med hver deres særkende. I den første tid, fra november 1849 til marts 1850 , forte den en offensiv politik, hvor den over for den danske statsledelse og omverdenen søgte at markere sit synspunkt. Fra marts til juli 1850 var dens aktioner af mere defensiv art, idet de var fremprovokeret af slesvigholstenske aktioner. Den tredie periode, som varede fra freden i Berlin i juli 1850 til efteråret 1851, var præget af, at Danmark igen besad den fulde magt $i$ hertugdømmet, men ogsa af frygt for, at regeringens ejderpolitik, som man anså Tillisch som garant for, skulle blive opgivet.

\section{Tiden november 1849 - marts 1850}

Det første forsøg på en aktion fra den fælles Slesvigske Forenings side kom kort efter Nørbymødet. Rygter i Flensborg sagde i november 1849, at den slesvig-holstenske hær forberedte indfald i Slesvig fra Holsten, hvortil den havde trukket sig tilbage. Da der ikke syntes at være truffet modforholdsregler fra dansk side, måtte man frygte for den slesvigske centralkasses sikkerhed. Den var folkets ejendom, 


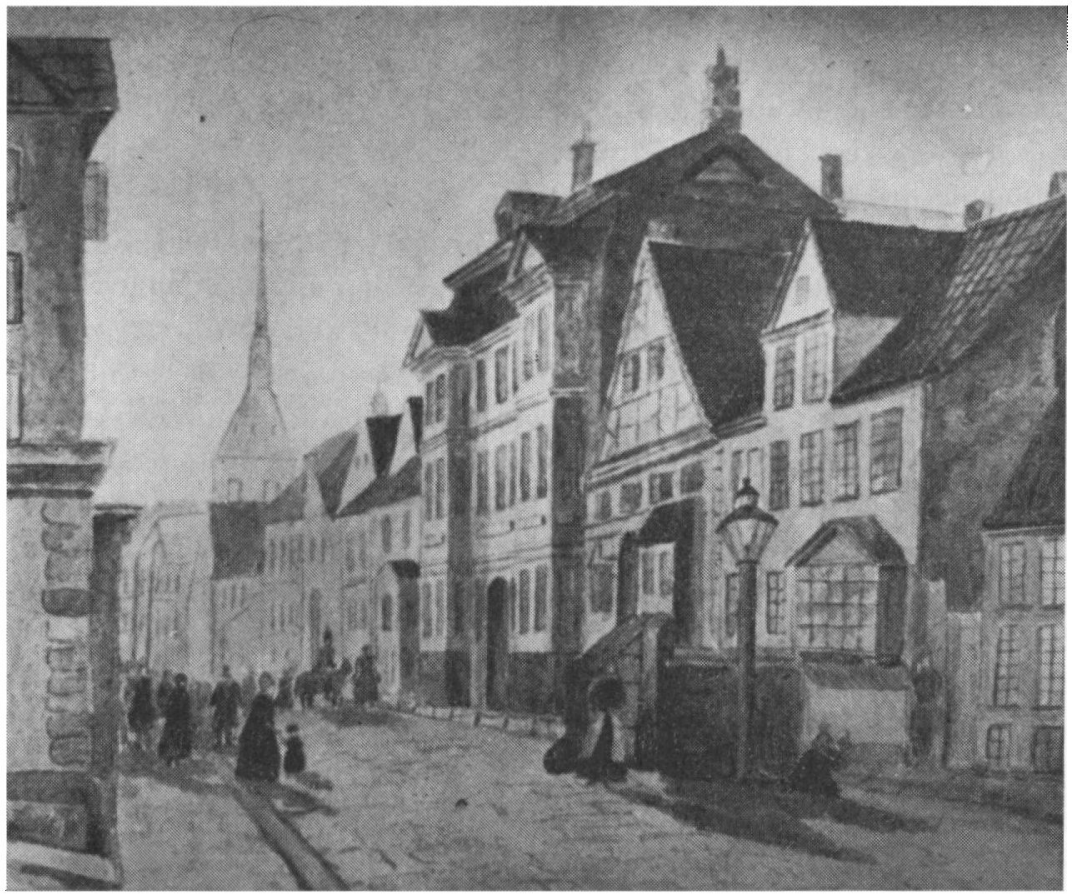

Andreas Christiansens bjem, patricierbuset Holm $12 i$ midten af billedet. Her boede det danske medlem af den midlertidige bestyrelseskommission for Slesvig, kammerberre F. F. Tillisch under sit ophold $i$ Flensborg 1849-50. Huset blev nedrevet $i$ 1911. (Det kongelige Bibliotek).

og folket kunne og måtte forvente af foreningen, at den handlede $\mathrm{i}$ en sådan sag, mente Christiansen. Han opfattede altså foreningen som repræsentation for folket. Kassen burde ikke forblive i Flensborg, men føres ombord på et dampskib eller i sikkerhed i Sønderborg. En petition herom burde dog ikke udgå fra Flensborg, da den ville forurolige folk endnu mere, men fra filialforeningerne i Haderslev og Åbenrå. ${ }^{6}$

I løbet af et par dage fik overdirektionen den onskede adresse fra foreningen i Haderslev. Frederik Fischer i Ảbenrå synes derimod at have frarådet aktionen ud fra den betragtning, at den ville svække bestyrelseskommissionen ved at antyde mangel på tillid til dens forsigtighed. ${ }^{7}$ Tillisch var dog klar over de loyales frygt, og bestyrelseskommissionen havde straks taget forholdsregler til kassens sikring. ${ }^{8}$ 
Christiansen måtte nu give Fischer ret $i$ hans vurdering. ${ }^{9}$ Det var en kedelig optakt til samarbejdet mellem de tre foreninger, at den Slesvigske Forenings præsident næppe havde undersøgt sagen grundigt nok, og i hvert fald fejlbedømt situationen.

Også på anden måde gav foreningen udtryk for manglende tro på bestyrelseskommissionens handlekraft, hvilket den mente skyldtes preussernes træskhed. I december 1849 henvendte den sig $i$ en petition til statsrådet $\mathrm{i}$ København. Overdirektionen konstaterede med bekymring, at våbenstilstandsaftalen ikke blev overholdt i Sydslesvig. Bestyrelseskommissionen manglede magt til at bringe sine bestemmelser til udførelse, ja dens magtesløse befalinger havde kun gjort den latterlig i befolkningens øjne. Mildhed ville aldrig påvirke slesvigholstenerne. På grund af kommissionens langmodighed var dens embedsmænd blevet mishandlet og skatterne ikke betalt, da dens trusler ikke var blevet realiserede. Overdirektionen mente, at to forhold var skyld i denne mislige situation, dels selve våbenstilstandens udformning, dels og især den preussiske politik, som omgik konventionens bestemmelser. Derfor ville ro og orden være umulig, og kongens loyale undersåtter fortsat føle sig værgeløse, så længe der var preussiske eller overhovedet tyske tropper $\mathrm{i}$ hertugdømmet Slesvig. Overdirektionens bon til statsrådet var derfor, at Preussens politik ikke længere måtte have indflydelse på Slesvigs forhold, og, ifald omstændighederne ikke tillod en dansk besættelse af hertugdømmet, at en besæettelse $i$ hvert fald ikke skete med tropper, som tidligere havde været underlagt den tyske centralmagt og som sådanne været delagtige i oprøret. ${ }^{\mathbf{1 0}}$

Den netop dannede gråstenske filialforening sluttede sig også hertil, og Frederiksklubben tilføjede, at den ulykkelige situation i Sydslesvig også styrkede modet hos det parti, som gik ind for oprøret.11 På grund af sit kritiske indhold egnede petitionen sig ikke til offentliggørelse og blev derfor kun underskrevet af filialforeningernes direktioner. Den havde således ikke givet dem meget besvær. På den anden side kunne statsrådet ikke stille meget op med denne klage over bestyrelseskommissionens afmagt i Sydslesvig. Efter at have cirkuleret blandt ministrene blev adressen derfor henlagt. ${ }^{12}$

På dette tidspunkt arbejdede foreningen også på sit langtidsmål for Slesvigs fremtid. En stor petition til kongen skulle anmode ham om opfyldelsen af løfterne i proklamationen af 27 . marts 1848 . Løf- 
terne citeredes $\mathrm{i}$ deres helhed. De var alt, hvad underskriverne som slesvigere ønskede. Deres bøn til majestæten var derfor, at der ved de kommende fredsforhandlinger intet måtte blive fastsat, som kunne hindre, at Slesvigs forbindelse med kongeriget blev så fast, at deres børn i fremtiden måtte være sikret imod en gentagelse af den ulykke, som det sidste halvandet år havde hjemsøgt landet. ${ }^{13}$

Denne adresse til kongen skulle stotte regeringen ved fredsforhandlingerne og derfor indsendes, før disse begyndte for alvor. Efter et betydeligt arbejde fra foreningens side fik adressen meget stor tilslutning i befolkningen, så tidsrammen sprængtes.

Indsamlingen af underskrifter begyndte vel i slutningen af november 1849. Der skulle være social bredde i petitionen - Christiansen pointerede, at såvel den lille mand som den besiddende og jordbesiddende skulle skrive under og dermed yde sit til statens opretholdelse - og så mange underskrivere som muligt. Christiansen foreslog derfor Fischer, at det kunne være tilrådeligt at lade adressen transportere rundt med håndværkere som glarmestre og slagtere og med handlende for at få folk i Åbenrås omegn til at skrive under. ${ }^{14}$

I Flensborg var indsamlingen allerede ved at være afsluttet $i$ begyndelsen af december $1849 .{ }^{15}$ Kort efter modtog overdirektionen de 6 eksemplarer af adressen fra farver Jürgensen i Gråsten med en meddelelse om, at adressen fra Rinkenæs også snart kunne ventes. ${ }^{16}$ Derimod var der vanskeligheder med at få adresserne fra Ảbenrå og Haderslev. Der var ikke så mange underskrifter som ventet på de åbenråske, og for at modvirke det uheldige indtryk foreslog Christiansen Fischer, at man $i$ en omstående attest anforte, hvad der havde afholdt de ellers så loyalt sindede beboere fra at skrive under. ${ }^{17}$

Ved juletid 1849 var der indsendt adresser fra næsten alle sogne $i$ Haderslev vesteramt, men så godt som ingen fra osteramtet, men da våbenstilstandens afslutning nu nærmede sig, pressede overdirektionen på for at få de sidste indsamlet. Sent kom adresserne fra østeramtet, ${ }^{18} \mathrm{og}$ på grund af frygten for den slesvig-holstensksindede borgmester Kier i Haderslev kom underskrifterne herfra endnu senere. Der var også kommet underskrifter fra Angel. I februar kom omsider de sidste af de 9011 underskrifter på adressen til Flensborg. Det var en betydelig opbakning, adressen havde fået. Kun én gang før, $i$ slutningen af 1848 , havde en loyal adresse fået større tilslutning i befolkningen. ${ }^{10}$ 
Dr. Levestamm havde imens forhørt sig fortroligt hos Tillisch, hvordan den danske regering så på, at adressen også afleveredes til de venligtsindede stormagter. ${ }^{20} \mathrm{Da}$ Tillisch spurgte statsrådet, fandt dette, at det var meget ønskeligt, at en sådan udtalelse fremkom, men at man kunne nøjes med at overbringe den til den mæglende magts regering, altså til den engelske udenrigsminister lord Palmerston. Statsrådet lagde i øvrigt megen vægt på, at adressen også offentliggjordes $\mathrm{i}$ aviserne. Derved ville dens virkning øges. Det skete også senere hen. ${ }^{21}$ Udkastet til den Slesvigske Forenings henvendelse til stormagterne var vist en højtravende udtalelse på fransk af $\mathrm{dr}$. Levestamm. ${ }^{22}$ Statsrådet lavede et helt andet udkast til henvendelsen til England, som efter nogle få ændringer fra Tillischs hånd den 5. marts 1850 overraktes oberst Hodges af en deputation fra foreningen sammen med en afskrift af kxmpeadressen..$^{29}$ Originaladressen sendtes samtidig til Kobenhavn, hvor den sikkert fandt en velvillig modtagelse. ${ }^{24}$

Hodges havde anbefalet sin udenrigsminister at give et beroligende svar på denne henvendelse, da der $\mathrm{i}$ den sidste tid var opstået megen forbitrelse blandt de dansksindede. ${ }^{25}$ Palmerstons svar var i overensstemmelse hermed, at den engelske regering ville gøre alt for at sikre en heldig afslutning af forhandlingerne mellem Danmark og Tyskland, og at den håbede, at det tidspunkt ikke var fjernt, hvor underskriverne af adressen ved en sikker og ærefuld fred ville blive belønnede for deres loyalitet imod deres konge og for deres tålmodige og ordentlige udholden af de talrige onder, som uundgåeligt ramte et land, der blev krigsskueplads. ${ }^{26}$ En kopi af dette svar sendte Christiansen som ventelig statsrådet til underretning. ${ }^{27}$

Den nystiftede angelske filialforening havde nok givet sin tilslutning til den store adresse; men i en separatadresse til kongen, underskrevet af 153 medlemmer $i$ januar 1850, gav den udtryk for en noget anden indstilling. Der henvistes heri til en kongelig proklamation af 27 . august 1849 , som var meget konservativ i forhold til proklamationen af 27. marts 1848. Forskellen ses lettest ved, at 1848proklamationen lovede slesvigerne en fri forfatning, hvis de ville være kongen tro, mens 1849-proklamationen fremhævede, at de slesvigere, som havde bevaret troskaben, ville have den bedste løn i deres egen bevidsthed og $\mathrm{i}$ det eksempel, de efterlod deres børn! Den fri forfatning nævntes ikke $i$ denne proklamation. ${ }^{28}$ I nøje overenstem- 
melse med denne konservative ånd handlede den angelske takadresse om majestætens kærlighed til slesvigerne og filialforeningens kærlighed og tak til majestæten. Den ærede lov, ret, sædelighed og orden i folket. ${ }^{29}$ Over for Palmerston afgav denne aktive filialforening også en erklæring i samme ånd underskrevet af 291 mænd. De fandt, at der ikke ville være nogen velsignelse $i$ landet, før kong Frederik den 7.s retfærdige hånd atter beherskede det. I bestyrelseskommissionens håndhævelse af loven så disse angelboer kun en ordnet øvrighed, som var af Gud og indsat af kongen, som den anså som sin eneste retmæssige herre. Af Palmerston ønskede filialforeningen kun hans medvirken til, at den fremmede indblanding i Slesvigs anliggender kunne ophøre, så der kunne komme fred $\mathrm{i}$ landet. ${ }^{30}$ Palmerston gav på dette et lignende svar som til overdirektionen. ${ }^{31}$ Også den Danske Forening for Als og Sundeved sendte en adresse til Palmerston, som fulgte linjen i den Slesvigske Forenings henvendelse, og som den derfor ikke modtog noget svar på. ${ }^{22}$

I den store adresse til kongen havde den Slesvigske Forening erindret om løfterne $i$ proklamationen af 27 . marts 1848 , men ikke sagt noget om hvornår og hvordan, de burde indfris. Dette problem drøftedes allerede $i$ december 1849 af de ledende mænd i de tre oprindelige foreninger. ${ }^{33}$ Den 30 . januar 1850 skulle den danske rigsdag åbnes med deltagelse af to slesvigere, Laurids Skau og Knud Knudsen fra Forballum, og den tanke var derfor ikke fjern at lade dem representere foreningens synspunkter. De indkaldtes til et møde med representanter for de loyale $\mathrm{i}$ hertugdømmet den 18 . januar hos gastgiver Caspar Hansen i Logumkloster. Initiativet dertil kom nok fra H. A. Krüger, Bevtoft, ${ }^{34}$ og samlede ud over ham og et antal ansete mænd fra Tønder, Ảbenrå og Løgumkloster amter også repræsentanter for den Slesvigske Forening i Flensborg og Frederiksklubben i Ảbenrå.

På mødet var dog af de to rigsdagsmænd kun Knudsen til stede. Det har næppe heller været så nødvendigt for Skau, som var medlem af filialforeningens direktion i Haderslev og deltager i Nørbymødet, at deltage $\mathrm{i}$ Løgumklostermødet. Forsamlingen tog naturligvis bestemt afstand fra oprørerne og tilsluttede sig bestyrelseskommissionen som den eneste lovlige regering $i$ landet. Med hensyn til fredsslutningen og Slesvigs fremtid udtalte forsamlingen med akklamation, at slesvigerne havde tre ønsker: 
1. En fast og inderlig forbindelse med Danmark, og at kongen skulle beskytte slesvigerne mod en selvstændighed, som kunne blive farlig.

2. Slesvigs udelelighed.

3. Slesvigs befrielse fra Holsten, hvortil det ikke ville knyttes med noget bånd, af hvad navn det så end kunne kaldes.

Desuden holdt Krüger og Andreas Christiansen taler, i hvilke embedsstanden og adelen betragtedes som oprorets årsag, og som modtræk mod deres indflydelse blev bl. a. foreslået, at jurister ikke burde have ikke-juridiske embeder. Der burde tillige indføres frie kommuner, offentlig mundtlig rettergang og forligelseskommissioner med dømmende myndighed. Men en fri forfatning kunne og burde ikke indføres med det samme i hertugdømmet. ${ }^{35}$

Christiansen rejste derpå $\mathrm{i}$ barsk vintervejr til Haderslev for at delagtiggøre direktionen dér $\mathrm{i}$ disse resultater. Den var ganske enig $\mathrm{i}$ det ønskelige $i$ en stadig kontakt til den danske rigsdag og $i$, at man gennem overdirektionen skulle meddele de to rigsdagsmænd den Slesvigske Forenings bestemte mening om hertugdømmets fremtid og også give dem de nødvendige beretninger om folkestemningen her. Knudsen og Skau var at betragte som foreningens repræsentanter i Rigsdagen. I denne situation kommer foreningens funktion som parti endnu tydeligere frem. Knudsen havde åbenbart på mødet accepteret tanken, og Skau kunne ikke være i tvivl om hensigten, idet Christiansen straks sendte ham protokolekstrakt af mødet i Haderslev-direktionen samt en afskrift af den adresse, som var blevet resultatet af drøftelserne i Løgumkloster og Haderslev. ${ }^{36}$ Overdirektionen havde dog senere næppe megen kontakt med de to rigsdagsmænd; men $i$ en enkelt situation $i$ november 1851 sendte den dog Skau afskrift af en adresse, for at han kunne meddele Rigsdagen den. ${ }^{37}$

Resultatet af overvejelserne i Løgumkloster og Haderslev var blevet en adresse til kongen, som specificerede den Slesvigske Forenings ønsker om Slesvigs fremtid på grundlag af proklamationen af 27. marts 1849. Denne adresse viser altså noget nøjere, hvor foreningen placerede sig politisk. Adressen fastslog, at for at virkeliggøre Slesvigs selvstændighed - hvad der var den danske regerings grundsynspunkt i skarp modsætning til den slesvig-holstenske opfattelse - for så vidt den kunne bestå med den almindelige stats vel, foreslog man 
en ny organisation med en bestemt repræsentation på den danske rigsdag i alle almindelige, hele staten vedkommende spørgsmål, og en speciel landdag for Slesvigs anliggender. Den Slesvigske Forening mente dog, at det ville være imod Slesvigs sande interesser at have en særlig slesvigsk minister, men derimod ikke at have slesvigske kontorer $\mathrm{i}$ de fælles ministerier. I lokaladministrationen af Slesvig skulle hertugdømmet opdeles i 7-8 store landdistrikter, som hvert indesluttede en købstad og var ledet af en prxsident under centraladministrationens ministerier $\mathrm{i}$ København, altså en slags amtmand for både by og land. Justitsen skulle også omorganiseres i den retning, som var skitseret på Løgumklostermødet. Men hvornår disse ønsker skulle gå $i$ opfyldelse, skulle kongen selv bestemme, hed det $i$ adressen. Men en fremmed magt (Preussen) måtte ikke kunne blande sig $i$ danske anliggender. Derfor måtte den fri forfatning udsættes, til der herskede ubetinget lydighed imod regeringen. De loyale slesvigere nærede tillid til, at der ikke i mellemtiden ville ske skår i Slesvigs nøje og virkelige tilslutning til kongeriget eller dets materielle og åndelige adskillelse fra Holsten og Lauenborg. ${ }^{38}$

Det ses således, at foreningens ledelse af liberale flensborgske købmænd nok ønskede en fri folkelig forfatning, men ikke indført straks, hvis dette betød, at slesvig-holstenerne igen vandt indflydelse. Vigtigst for foreningen var at sikre den statsretslige forbindelse med kongeriget, og at slesvig-holstenernes magt stækkedes $i$ fremtiden. Administrativt skulle Slesvigs stilling til kongeriget blive, hvad den havde været til Holsten før 1848. Inddelingen i 7-8 områder under overpræsidenter i nær kontakt med København skulle formindske den provinsielle slesvig-holstenske indflydelse og ydermere give administrativ ensartethed i hertugdømmet, som netop var kendt for sin store forskelligartethed indenfor administrative og retslige forhold. Dette ville ligesom ændringerne $\mathrm{i}$ justitsen have mindsket advokaternes betydning, og de var jo netop fortrinsvis slesvig-holstenere. Endelig ville fri kommuneforhold nok have styrket de lavere klasser, hvor slesvig-holstenerne kun havde ringe indflydelse.

Tiden marts - juli 1850

Dagen efter afleveringen af den store adresse til oberst Hodges kom en preussisk kommissær Vollpracht, der uofficielt skulle sondere stemningen $\mathrm{i}$ hertugdømmerne, til Flensborg. Det danske statsråd 
havde instrueret sin gesandt i Berlin om at protestere imod dette brud på våbenstilstandskonventionen. Dette gjorde han og meddelte desuden Tillisch i Flensborg, at det var meget vigtigt, at bestyrelseskommissionen undgik enhver officiel kontalt med Vollpracht, da hans indgriben i Slesvig var ganske ubeføjet. ${ }^{39}$ Dette standpunkt stod den Slesvigske Forening også på og burde af den grund undlade enhver forbindelse med ham; men foreningen var på den anden side nødt til at modvirke de slesvig-holstenske indtryk, kommissæren ville få, og kunne som uofficielt organ også gøre det. Vollpracht blev derfor ikke kun opsøgt af de slesvig-holstensksindede, men også af de loyale. Endda fra filialforeningen i Angel kom der en deputation med en adresse, som udtalte, at den overlod det til kongen at ordne Slesvigs forhold, men at proklamationen af 27. marts 1848 var retningsgivende for den - her fulgtes altså overdirektionens linje.

Fra de loyale i Flensborg kom flere deputationer, der udtalte sig for en nærmere forbindelse med kongeriget. ${ }^{40}$ Det var den Slesvigske Forening $\mathrm{i}$ byen, deputerede fra Handelsforeningen, Borgerforeningen og af skippere og søfarere. Deres henvendelse skete sandsynligvis i samråd med overdirektionen. Det var i hvert fald tilfældet med skippernes. Disse gjorde straks Vollpracht opmærksom på, at Tyskland ikke havde ret til at sende kommissærer for at undersøge folkestemningen, men at de ville oplyse ham om flertallets synspunkter. P̊̊ hans bemærkning om, at slesvigerne onskede selvstændighed, svarede denne deputation, at de fleste slesvigere hellere onskede den tættest mulige forbindelse med kongeriget og åndelig såvel som materiel adskillelse fra Holsten, og at proklamationen af 27. marts 1848 indrømmede slesvigerne mere frihed, end det syntes dem gavnligt for Slesvigs vel. Andreas Christiansen var i stand til at referere dette nøje, for blandt medlemmerne af deputationen var dr. Levestamm, som i øvrigt ville overrække Vollpracht den af ham selv forfattede adresse til stormagterne, som havde været foreslået den flensborgske direktion; men andre, bl. a. Christian Hansen jr., altså endnu et fremtrædende medlem af foreningen, fandt, at dette gik ud over deres beføjelser. ${ }^{41}$ Overdirektionen vidste vel, at der ikke var meget at opnå ved deputationer; men på den anden side kunne de ikke skade. Den skyndte sig derfor at forberede filialforeningerne i Åbenrå og Haderslev på, at Vollpracht måske ville rejse derhen. ${ }^{42}$

Af lignende defensiv art var en protestadresse kort efter, som var 
foranlediget af en gruppe slesvig-holstenere, der var rejst til Berlin som »deputation « fra hertugdømmet Slesvig. Foreningen stilede adressen til den danske gesandt $\mathrm{i}$ Berlin og forsikrede ham om, at størstedelen af Slesvigs befolkning var loyalt sindet, og at det var en anmasselse fra disse personer at kalde sig deputation, da de ikke engang var valgt dertil af den vildførte minoritet af den slesvigske befolkning. Det var kun direktionerne, som skrev under på adressen, da befolkningen var træt af underskriftsindsamlinger efter kxmpeadressen til kongen $\mathrm{i}$ begyndelsen af året. Dog kom der en adresser til gesandten $i$ den sædvanlige kongetro stil fra Angel underskrevet af 120 beboere. ${ }^{43}$

Overdirektionen følte derimod, at det var en betydeligt farligere situation, da der $\mathrm{i}$ begyndelsen af april 1850 sendtes en slesvigholstensk deputation til København. Foreningen i Angel foreslog at modvirke dette forsøg på at vinde tid og vildføre den danske regering ved selv at sende en deputation til København. På »højere sted «, vel Tillisch, var man også af den mening, at det ikke kun ville være en god, men også nødvendig forholdsregel.44

I løbet af få dage lykkedes det at få valgt repræsentanter fra de fleste filialforeninger og egne, hvor der ikke eksisterede en sådan. ${ }^{45}$ Lørdag den 20. april afgik deputationen med dampskibet Waldemar fra Flensborg. Deltagerne var senator, farver Bahnsen fra Ảbenrå, købmand de Wolff fra Haderslev, købmand Erich Hansen fra Flensborg, Stadthauptmann Hansen, Sønderborg, fra den Danske Forening for Als og Sundeved, gårdejer, deputeret $\mathrm{H}$. A. Krüger, Bevtoft, fra Haderslev vesteramt, gårdejer Evald Clausen fra Harreslev, gårdejer Jes Jessen fra foreningen for Gråsten. ${ }^{46}$ Det var således ikke formændene, der var blevet afsendt. Jes Jessen havde fra sin direktion fået en instruks, som byggede på den store adresse til kongen, nemlig at der ikke måtte ske noget skår i Slesvigs nøje tilknytning til kongeriget $i$ tiden, før det fik en fri forfatning, samt at oprørets ledere skulle drages til ansvar. ${ }^{47}$ I København holdt deputationen samråd og valgte som ordfører Erich Hansen fra Flensborg. Nu afsløredes det, at overdirektionen allerede havde udformet den adresse, der skulle overrækkes kongen. Den fandt nok alles bifald; men det blev fra alle sider bemærket, at den ikke var tilstrækkelig, og det kritiseredes, at adressen ikke på forhånd var blevet diskuteret af alle foreninger og repræsentanter for folket. Deputationen var bestemt 
ikke tilfreds med overdirektionens handlemåde og formulerede nu selv petitionen, som afleveredes $i$ audiensen hos kongen på Frederiksborg den 23. april.48

Petitionen protesterede indledningsvis imod den holstenske deputation, som anmassede sig til at optræde på slesvigernes vegne. Derpå gentog deputationen foreningens politiske opfattelse ud fra kongens proklamation af 27 . marts 1848 . Deputationen frygtede dog, at en øjeblikkelig gennemførelse af proklamationen ville vanskeliggøre forholdene, og bad derfor kongen regere suverænt, men i proklamationens ånd, for en tid, indtil orden igen havde indfundet sig ved tilflytning af loyale embedsmænd. Dette kunne lettest gøres ved at flytte nordslesvigske loyale embedsmænd til Sydslesvig og anbringe danske kandidater med kendskab til slesvigsk ret i Nordslesvig. Sluttelig foreslog deputationen, at der før indførelsen af en slesvigsk landsforfatning burde indføres et kommunevæsen, og en fri udvikling af kommuneforholdene fremmes, for at folkets deltagelse $i$ offentlige anliggender kunne få en fast grundvold. ${ }^{49}$

Frederik 7. svarede deputationen meget venligt og nævnte særlig proklamationen af 1848 som den basis, hvorpå Slesvigs stilling efter hans kongelige vilje burde ordnes. Det gjorde sikkert et dybt indtryk på deputationen, at han bad den om at tage en hilsen med hjem til hans kære, tro slesvigere. Derpå blev den indbudt til taffel hos kongen og senere opfordret til at bese slottets mærkværdigheder. I de følgende dage knyttede deputationen kontakter med de danske ministre, så resultatet for den Slesvigske Forening må betegnes som yderst positivt. ${ }^{50}$

Det problem, der lå bag deputationens afsendelse, nemlig at hindre slesvig-holstenerne $i$ at vinde gehør for deres tanker $i$ København, løstes dog ikke. ${ }^{51}$ Andreas Christiansen mente fejlagtigt, at nye adresser bare ville være gentagelser og derfor overflødige, medmindre de undertegnedes af den ganske befolkning, hvad der ikke var tid nok til. Med hensyn til udsendelsen af representanter konstaterede han trist, at slesvig-holstenerne havde mere opbakning end de loyale slesvigere. Måske kunne man løse problemet ved at sende delegerede til København for en læengere tid for at overvåge, hvad der skete af interesse for Slesvig. Ved indirekte valg fra filialforeningerne og de distrikter, hvor foreninger ikke fandes, burde de udpege én eller flere repræsentanter. Ved at foreslå dette over for $\mathrm{H}$. A. Krüger var 
det vel Christiansens hensigt, at han skulle gå ind på ideen, hvad der vist ikke skete. Efter storkøbmanden Andreas Christiansens mening ville de nødvendige penge ikke frembyde noget problem, dog var det sikkert pengemangel, som var den stærkeste hindring for et sådant projekt. ${ }^{52}$

\section{Tiden juli 1850 - juli 1851}

I det følgende års tid var den Slesvigske Forenings politik endnu mere præget af forholdet til Tillisch, som man nu åbent erklærede var garanten for den politik og administration i Slesvig, som foreningen ønskede. Tillischs mål var nu at skabe den højest mulige forening mellem kongeriget og hertugdømmet Slesvig og den størst mulige adskillelse mellem hertugdømmerne Slesvig og Holsten, og det var jo netop foreningens erklærede mål. Han mente dog også, at man ville skuffes, hvis man antog, at hele det loyale parti eller endog den største del af det var enig heri. Derimod var alle enige $i$ en ubetinget tillid og hengivenhed til kongen, og dette foreningspunkt antog han, at man burde se at nå og sikkert ville nå.53 Det kan derfor ikke undre, at forholdet mellem den Slesvigske Forening og Tillisch var godt.

$\mathrm{Da}$ nu tiden for våbenstilstandsperiodens ophør nærmede sig, forberedte den danske regering sig på at skulle overtage styret igen $\mathrm{i}$ Slesvig. Blandt de personer, som Tillisch fandt skulle deltage i administrationen, var grev Carl Moltke og L. N. Scheele begge konservative helstatsmænd. ${ }^{54}$ Regeringen havde også tænkt på en mulig anvendelse af tidligere regeringsråd Johannes Höpfner som ny departementschef. ${ }^{55}$ Slesvig-holsterne hadede disse mænd, og hos de loyale var disse loyale holstenere heller ikke populære. Men Tillisch havde tænkt sig at anvende disse eksperter $\mathrm{i}$ administrationen, og ved en adressekampagne fra de loyale i Slesvig til fordel for de nævnte herrer ville han kunne udviske indtrykket af, at alle $i$ hertugdømmerne var imod dem. En holstensk delegation i Kobenhavn havde nemlig udtalt sig imod deres anvendelse i den slesvigske administration.

Udkastet til denne adresse synes $\mathrm{dr}$. Levestamm at have forelagt Tillisch den 17. juni 1850, før det fremlagdes $\mathrm{i}$ et direktions- og komitémøde. Han bad Tillisch om efter forgodtbefindende at tilføje eller stryge noget, eventuelt det hele. ${ }^{56}$ Nogle dage senere sendtes 


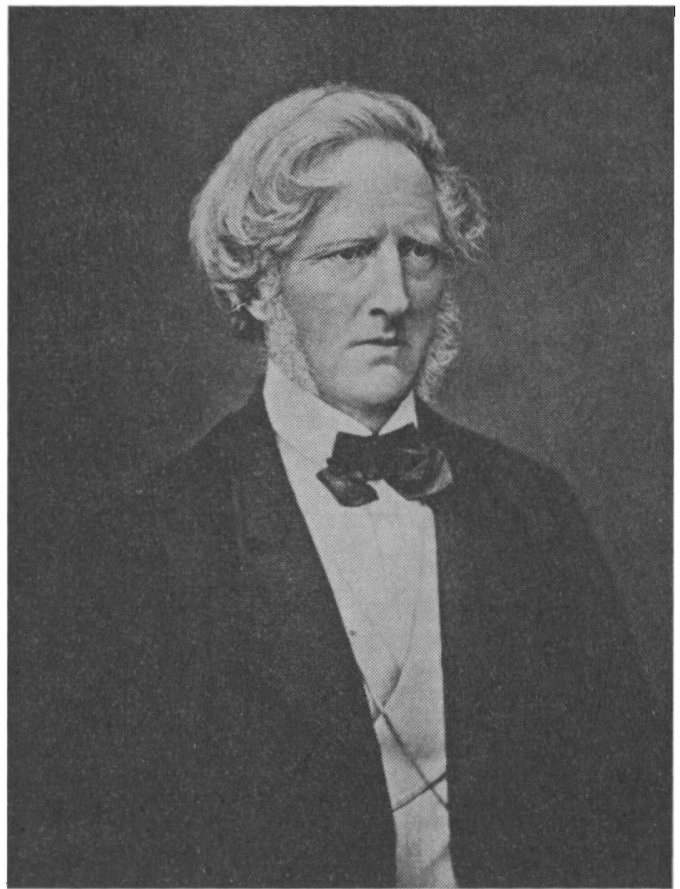

Dannevirkes redaktør Peter Christian Koch (1807-80) var blandt de ledende $i$ den haderslevske filialforening og var dens kontaktmand til overdirektionen $i$ Flensborg. (Historiske Samlinger for Sonderjylland).

adressen til filialforeningerne og til Krüger i Bevtoft og dr. Levin i Løgumkloster. Apoteker Nagel, som netop havde dannet en ny Slesvigsk Forening, fik den også tilsendt. ${ }^{57}$

Filialforeningerne, dr. Levin og apoteker Nagel samt den Danske Forening for Als og Sundeved underskrev adressen; men Haderslev ville ikke. ${ }^{58}$ Redaktor Koch meddelte straks, at man afslog at underskrive adressen. Overdirektionen segte at presse direktionen til underskrift ved at henvise til, at der var kommet positive svar fra næsten alle steder, og at direktionen i Haderslev som den eneste repræsentant for byens loyale befolkning ikke kunne unddrage sig det. ${ }^{59}$

Den haderslevske direktion fandt derimod, at hvis man i modsætning til den holstenske deputation udtalte tillid til Scheele og Moltke, så accepterede man tanken om særegne slesvigske institutioner som et 
slesvigsk statholderskab, statsråder, hvad man ikke ville og derfor heller ikke ville foreslå kongen eller rigets ministre. ${ }^{60}$ Naboforeningen i Aller kunne heller ikke tiltræde adressen, men motiverede ikke engang sin afvisning af den. Dette frembragte et noget skarpt svar fra overdirektionen, at vel var det en selvfølge, at enhver direktion skulle handle efter sin overbevisning; men en filialforening var også de andre skyldig at angive sine bevæggrunde, og ikke kun dissensen. ${ }^{61}$

Fire dage efter freden i Berlin, den 6. juli 1850 kunne overdirektionen sende de onskede tillidsadresser til statsrådet. ${ }^{62}$ Foreningen $i$ Angel havde sendt sin som en af de sidste. Den onskede, at Scheele udelt måtte bevare kongens nåde og velvilje. ${ }^{63} \mathrm{I}$ modsætning hertil var Krügers holdt som en almenerklæring. Med henvisning til denne form fik Andreas Christiansen overtalt direktionen i Haderslev til at sende en tilsvarende almen erklæring. Her hed det, at de slesvigholstenske udsendinge i København havde fremstillet de mænd, som var forblevet deres konge og ed tro, som forhadte af folket og derfor ubrugelige til slesvigske embeder. Dette var vitterlig en usandhed. Den haderslevske filialforening forsikrede, at den villigt og gerne adlød enhver embedsmand, som havde kongens tillid, og at det ville være en sjælden og stor anbefaling for en embedsmand, at han ingen sympati havde for det oprørske parti. ${ }^{64}$ Adresserne læstes i statsrådet; men fik ellers ingen betydning, $\mathrm{da}$ de nævnte mænd alligevel ikke blev inddraget $i$ hertugdømmets administration. ${ }^{65}$ Men sagen havde igen vist forskellene imellem de enkelte dele af foreningen.

Kort efter kom det til det blodige slag ved Isted, og den danske magt strakte sig atter ned til Danevirke. De loyale slesvigere glædede sig over denne fremgang. Formanden for filialforeningen i Skovsende ville indsende en adresse til »den danske hær«. Overdirektionen mente, at takken hellere burde udtales gennem krigsministeren; men først skulle den forelægges de andre filialforeninger. Adressen synes derpå at være blevet syltet. ${ }^{66}$ Overdirektionen mente heller ikke, at det ville være rigtigt eller finde almindelig tilslutning at give regeringen et tillidsvotum $i$ de første dage af dens herredømme, sådan som M. A. Jürgensen $\mathrm{i}$ Gråsten åbenbart havde gjort. Regeringen skulle nu med hærens fremrykken udfolde den største virksomhed og handle strengt upartisk. ${ }^{67}$

Overdirektionen var åbenbart i nær og enig kontakt med Tillisch. Et par måneder senere takkede foreningen i Angel dog Tillisch i de 
sædvanlige højstemte udtryk og bad ham om ikke at opgive værket, selv om frugterne ikke viste sig straks. ${ }^{68}$

Derimod blev spørgsmålet om de oprørske embedsmænd, et emne, som de harmdirrende loyale hele tiden havde $i$ tankerne, rejst meget hurtigt. På mødet i Løgumkloster den 18. januar 1850 havde forsamlingen foreslàet at andrage bestyrelseskommissionen om straks at få afsat de oprørske embedsmænd; men $\mathrm{H}$. A. Krüger havde mindet den om, at kommissionen kun var en halv dansk regering, og at man ikke onskede at få embedsmænd, som kun var lidt bedre. Forsamlingen opgav derfor dengang at andrage om dette. ${ }^{69}$ Men nu havde F. F. Tillisch som overordentlig dansk regeringskommissar overtaget styret af Slesvig med ansvar over for kongen alene. Regeringen var altså helt dansk. Den Slesvigske Forening gjorde nu Tillisch opmrrksom på, at en vigtig sag var at udrense embedsstanden, fra hvilken kimen til revolutionen var kommet. Foreningen bad derfor Tillisch om at have hele sin opmærksomhed henvendt på, at besættelsen af de højere embedsmandsstillinger skete med loyale retskafne mænd, gennemgladede af kærlighed til kongen og landets vel. ${ }^{70}$

Sxrlig nødvendig var adressen vel ikke, eftersom Tillisch allerede $i$ bestyrelseskommissionens tid havde haft dette for øje. Men den Slesvigske Forenings tilhængere kunne $\mathrm{i}$ det følgende halve år se, at Tillisch virkelig med fast hånd tog fat på de slesvig-holstensksindede embedsmænd.71

En vigtig højtstående embedsmandsstilling var ledelsen af Slesvigs kirke- og undervisningsnævn. Allerede i juli 1850 synes hadersleverne at have tænkt sig Flor som kultusminister og satte en adresse til kongen om dette $i$ omløb. ${ }^{72}$ Tillisch onskede næppe, at Flor skulle have denne post, og $\mathrm{i}$ hvert fald greb hans sekretær Regenburg særdeles kraftigt ind imod Flor gennem den Slesvigske Forening. Filialforeningen i Gråsten havde spurgt, hvordan det forholdt sig med denne sag, og svaret herpå affattedes af Regenburg, uden ændringer fra Christiansens side.

Regenburg nævnte først, at han tidligere havde ytret sig imod denne idé. Der var tre grunde dertil. For det første stred det imod foreningernes hidtidige grundsætninger kun at pege på en enkelt mand, nævnte Regenburg polemisk, idet han henviste til haderslevernes stejle holdning i tillidsadressesagen til Carl Moltke og Scheele. Dette interne foreningsanliggende kendte Regenburg altså. For det 
andet ville et andragende om et særskilt kultusministerium være $i$ modstrid med foreningens tidligere opfattelse af, at det var ønskeligt med den størst mulige forening mellem Slesvig og kongeriget. Skulle Slesvig få en særskilt bestyrelse - hvad der blev tilfældet - ville skole- og kirkevæsenet ikke behøve andet end en chef med kendskab til lovgivning og forretningsgang. Det var ganske andre egenskaber end de $\mathrm{i}$ adresseudkastet fremhævede hos Flor, og han ville næppe komme på den rette post, om han ellers ville modtage den. Hans hidtidige virke ville hæmme en sådan embedsmandsstilling og omvendt. Og for det tredie havde kongen udnævnt en notabelforsamling fra hele monarkiet til at fremsætte forslag til organisationen af hertugdømmets fremtidige bestyrelse. Det var derfor ubetimeligt at fremkomme med onsker og adresser derom, før kongen havde fået notablernes betænkning. ${ }^{73}$ Også filialforeningen i Bov meddelte overdirektionen denne opfattelse og lagde derved overdirektionens autoritet $\mathrm{i}$ vægtskålen til fordel for Tillischs synspunkt. ${ }^{74}$ Adressen fik alligevel betydelig tilslutning, og $\mathrm{i}$ slutningen af august 1850 kunne Tillisch ikke modvirke den på anden måde end ved at udnævne en anden person, nemlig Regenburg, som den 1. september $1850 \mathrm{blev}$ udnævnt til foreløbig at overtage de til kirke-, skole- og undervisningsvæesen henhørende sager. ${ }^{75}$ Håbet om at få Flor blev alligevel ikke opgivet. Adressen fik i Angel 217 underskrifter, 505 i Flensborg, 113 i Husum (!) og blev underskrevet af deputeretkollegierne i Ảbenrå og Haderslev, samt af direktionerne for filialforeningerne i Tyrstrup herred (Aller), Åbenrå, Tinglev og på Als. ${ }^{78}$ I denne sag var der altså også betydelig uenighed imellem foreningens forskellige dele.

Når der således var et nært samarbejde mellem Tillisch og den Slesvigske Forenings overdirektion, ville dette sandsynligvis også sætte sine spor på sammensæetningen af den notabelforsamling, som skulle nedsættes $i$ henhold til kongens kundgørelse af 14 . juli 1850 for at overveje en plan for monarkiets ordning. ${ }^{77}$ Notabelforsamlingens resultater ville selvfølgelig $i$ høj grad afhænge af, hvem der blev medlemmer, og isxr af de slesvigske medlemmer. Det synes, som om Tillisch fik en liste af Regenburg, hvor 7 af de 13 mænd havde en vis tilknytning til den Slesvigske Forening, mens finansminister grev Sponnecks liste rummede 3 eller 4 sådanne af 7 foreslåede mænd. Men Tillisch havde også spurgt Andreas Christiansen, om hvilke 
ansete mænd, han kunne foreslå. Hans svar kom allerede den 24. juli 1850 , altså før forholdene i Sydslesvig atter var i orden, så han kunne sætte sig i forbindelse med mænd dér. 8 eller 9 af de 10, Christiansen foreslog, havde en vis tilknytning til den Slesvigske Forening. De foreslåede var borgmester Lassen, købmand H. Wilhelm Schmidt, købmand Erich Hansen, broskriver Christian Hansen jr., alle Flensborg, deputeret oldermand Hans Jensen, H. A. Krïger i Bevtoft, dr. Claus Manicus, tidligere i Eckernførde, Stadthauptmann Hansen i Sønderborg, senator, farver M. Bahnsen i Åbenrå og regningsmand og gårdejer Dethlef Lassen i Strukstrup. ${ }^{78}$ Der rokeredes frem og tilbage med navnene på de slesvigske notabler, som til sidst blev professor Christian Paulsen, dr. Manicus, godsejer Hagemann, etatsråd Prehn, agent H. C. Jensen, købmand Caspar Christiansen (Andreas C.'s bror) H. A. Krüger, Laurids Skau og amtmand Davids. ${ }^{79}$ Det vil sige, at 5 eller nærmest 6 af de 9 slesvigske medlemmer havde tilknytning til den Slesvigske Forening. Det var da også Tillischs opfattelse, at notablerne burde vælges efter den hensigt at sikre det ejderdanske program ${ }^{80}$ At man ikke på dette punkt havde vurderet de slesvigske notabler (bortset fra Prehn) forkert, viste sig også, da de sammen med de seks danske notabler vedtog en ejderdansk flertalsindstilling. Dens tanker strandede imidlertid på holstenernes og tyske magters modstand..$^{81}$

Det var også udlandets modstand imod det tillischske regeringssystem, som tvang ham bort fra posten som slesvigsk minister. $\mathrm{Da}$ det i februar 1851 rygtedes, at Tillisch var ved at blive frataget posten som overordentlig regeringskommissær for Slesvig, var virkningen en vis opstramning af den Slesvigske Forening, som ellers var ved at gå noget i opløsning. Foreningens direktioner underskrev da to adresser til kongen, én om det ofte udtalte ønske at få en nærmere forbindelse med Danmark og en adskillelse fra Holsten, én om at måtte beholde Tillisch. ${ }^{2} \mathrm{Nu}$ blev Tillisch slesvigsk minister i marts 1851, og han fortsatte aktivt $\mathrm{i}$ dansk retning $\mathrm{i}$ hertugdømmet. $\mathrm{Da}$ hans afgang forlød i første uge af juli 1851, kom der derfor en proteststorm fra de loyale i Slesvig.

De 8 slesvigske notabler (Prehn var fraværende) udtrykte $i$ en skrivelse til premierministeren A. W. Moltke dyb bekymring over denne "kalamitet«. De frygtede nu for, at der ville ske et systemskifte og frugterne af tre års kamp forspildes. Det ville være en 
uoprettelig ulykke for landet at miste Tillisch, selv om der ikke tilsigtedes nogen systemforandring. De håbede at kunne beholde Tillisch. ${ }^{83}$

Overdirektionen sendte til premierministeren fire adresser, som udtrykte tillid til Tillisch. En storm satte ind, idet der den 11. juli indkom 31 tillidsadresser til Tillisch underskrevet af 1300 agtede mænd. ${ }^{84}$ Den Slesvigske Forening og de danske foreninger udtrykte det samme som notablerne (det var også en af dem, dr. Manicus, der forte pennen), nemlig at det var en kalamitet, og at de frygtede for, at det ikke kun var et person-, men også et systemskifte. ${ }^{85}$ Det blev både et person- og et systemskifte. Bardenfleth, Tillischs svoger, afløste ham som slesvigsk minister, og på den måde skete der ikke den store ændring; men hele ministeriet fik et stærkere helstatspræg, og efter det korte juliministerium skulle helstatspolitikken blive åbent proklameret i januar 1852. Det var dette skifte, den Slesvigske Forening frygtede.

\section{Foreningens reorganisering og ophør}

Ved nyheden om freden mellem Danmark og Preussen i Berlin, i følge hvilken Danmark nu skulle overtage magten $i$ hertugdømmet Slesvig fuldt ud, lyste Andreas Christiansen op: Nu var chancen der, nu skulle den Slesvigske Forening vokse sig stor. ${ }^{1}$ I denne retning peger også de visioner, han havde, om at foreningen med dens 11 afdelinger og 2-3000 medlemmer, som han oplyste overfor professor Christian Paulsen og minister H. N. Clausen, var det helt rigtige organ til udbredelse af gratis skrifter til befolkningen som modvægt til de tidligere slesvig-holstenske propagandaskrifter. Det var gennem pressen, at oprørernes ledere især havde påvirket sydslesvigerne. Havde staten tidligere anvendt nogle tusinde rdl. til vejledning af pressen, så var staten blevet sparet for lige så mange millioner, mente han. ${ }^{2}$ Derefter fulgte slaget ved Isted med dets mange faldne, og de loyale flensborgere fik andet at tæenke på.

Situationen var nu en ganske anden, nu hvor bestyrelseskommissionen var ophørt med at eksistere. Fra dansk side kunne man nu vise sin påskønnelse af Andreas Christiansen og indirekte af den Slesvigske Forening. Så tidligt som i december 1849 havde konseilspræsident Moltke spurgt Tillisch, om der ikke var mænd, som p.gr.a. 
loyalt sindelag og ofre for fædrelandet skulle belønnes med en nådesbevisning, - han tænkte navnlig på Christiansen. ${ }^{3}$ Tillisch troede dog ikke dengang, at det ville være hensigtsmæssigt. Som Tillischs ven og vært ville dette givetvis havde gjort et uheldigt indtryk af partiskhed. $\mathrm{Da}$ den yngre broder $\mathrm{C}$. Christiansen nu på en indstilling fra krigsministeriet blev udnæevnt til ridder, blev Andreas Christiansen det også med henvisning til, at han indtog en fremragende plads mellem de loyale slesvigere. ${ }^{4}$

I tiden derefter rejste Andreas Christiansen udenlands, vist til Sydtyskland og Frankrig $i$ tre måneder og vendte først hjem ved juletid 1850. I følge foreningens almene statutter skulle der $\mathrm{i}$ oktober afholdes generalforsamling, ved hvilken lejlighed den midlertidige overdirektions funktioner skulle ophøre. ${ }^{5}$ Tiden gik; men der kom ingen indkaldelse til generalforsamling. Medlemmerne i Flensborg synes ikke at have vidst, om Christiansen var rejst, og hvem der remplacerede ham som ledende direktør $\mathrm{i}$ foreningen. ${ }^{6}$ Foreningens virksomhed $i$ efteråret lå stille. Der kom fem breve fra filialforeninger til overdirektionen. ${ }^{7}$

Det ene brev var fra den store filialforening i Gråsten, som bekendtgjorde, at dens direktion og formænd fandt, at foreningens formålsparagraf nu for størstedelen var opfyldt, nemlig dens virke så længe bestyrelseskommissionen administrerede landet, og statutterne var derfor ikke længere svarende til øjemedet. Man ville indkalde til en generalforsamling $i$ slutningen af året og opløse forbindelsen til stamforeningen $\mathrm{i}$ Flensborg og $\mathrm{i}$ stedet danne et nyt patriotisk selskab, hvis hovedformål skulle være at stræbe efter bedre kommunale forhold. Skulle overdirektionen have nogle krav til den gamle filialforening, måtte dette ske inden fjorten dage. I øvrigt regnede Gråstenforeningen også med venskabelige forhold $\mathrm{i}$ fremtiden og samarbejde, hvis man stræbte efter et fælles mål. ${ }^{8}$ Det ville dog ikke berøre hele den store gråstenske filialforening, idet dens Felsted-distrikt i september-oktober havde konstitueret sin egen filialforening. ${ }^{\ominus}$

Andreas Christiansen gav den gråstenske forening ganske ret med de forslag for den Slesvigske Forenings fremtid, han lagde frem. Med udløbet af våbenstilstanden måtte den Slesvigske Forenings virksomhed hvile, da statutternes formålsparagraf for størstedelen var opfyldt. I ovrigt mente han heller ikke, at der eksisterede så meget foreningsaktivitet, at det nyttede noget at betale kontingent, hvad 
der jo var et andet ømt punkt, han rørte ved. Nok skulle foreningerne fortsat eksistere, eller rettere vegetere, for så kunne de i påkommende tilfælde repræsentere befolkningen over for regeringen, hurtigt skaffe adresser til veje o. s. v.

Når der ikke var blevet indkaldt til nogen generalforsamling i tide, skyldtes det, at overdirektionen havde ment at kunne udskyde den, til han selv, Andreas Christiansen, som ledende direktor, var vendt hjem. Det var i øvrigt kun foreningen i Gråsten, som i mellemtiden havde krævet en nøje overholdelse af statutterne, skrev han til foreningerne.

På overdirektionens vegne foreslog Christiansen nu, at generalforsamlingen $i$ stedet skulle afholdes den 5 . februar 1851, hvad der ifølge statutterne skulle bekendtgøres én måned tidligere $i$ aviserne. Overdirektionens dagsorden skulle have fire punkter:

1. Forslag om for en tid at lade foreningens virksomhed hvile.

2. Rådslagning om nyvalg af foreningsrepræsentanter og overdirektion.

3. Afsluttende oversigt over foreningens virksomhed.

4. Revision af årsregnskabet.

Da der ikke var tilstrækkelig plads til at samle et stort antal foreningsmedlemmer, foreslog Christiansen $i$ stedet at sende en reprxsentant med fuldmagt for hver enkelt filialforening. ${ }^{10}$

Dette udspil fra overdirektionens side afholdt foreløbig foreningen i Gråsten fra at gøre alvor af sin trussel om øjeblikkelig opløsning af forbindelsen til den Slesvigske Forening. Den ville deltage i generalforsamlingen, endda med to repræsentanter. ${ }^{11}$

Foreningerne reagerede dog ikke straks på overdirektionens forslag, hvad der bekræfter det tidligere sagte om deres ringe aktivitet og opbakning af overdirektionen. Mødet måtte derfor atter udsættes, til der var kommet svar fra alle, ${ }^{12}$ hvad der først skete omkring den 11. februar 1851. Mødet skulle derefter annonceres gratis i Dannevirke, Freia og Flensburger Zeitung, som var foreningernes blade. ${ }^{13}$

I spørgsmålet om den Slesvigske Forenings neddxmpning af sin aktivitet skiftede overdirektionen nu mening, fordi der var forlydende om, at regeringen ville tilbagekalde den overordentlige regeringskommissxr Tillisch fra Flensborg og erstatte ham med en »upassende lokalmyndighed. ${ }^{14}$ Denne nyhed, som vel stammede fra Til- 
lisch selv, medførte straks bestræbelser $i$ foreningen for at overbevise regeringen om de slesvigske tilstande, hvor Tillisch umuligt kunne undværes. Den Slesvigske Forening ville næppe heller kunne undvære Tillisch, hvis den ville have nogen større politisk betydning. $\mathrm{Da}$ stamforeningen i Flensborg den 21. februar 1851 valgte sine repræsentanter til generalforsamlingen, besluttede den derfor med stor majoritet at genoptage aktiviteterne, og dens repræsentanter skulle opfordre de andre til at samvirke under en ny overdirektion. Denne opfattelse tilsluttede overdirektionen sig. ${ }^{15}$

Til generalforsamlingen den 4. marts $1851 \mathrm{kl} .14$ i Philipsens lokale i Flensborg indbed overdirektionen representanter for alle filialforeninger, bortset fra Aller. Den inviterede også dr. Matthiesen fra Sønderborg samt særligt interesserede som Krüger, Bevtoft, og dr. Levin fra Løgumkloster. ${ }^{16}$ Repræsentanterne fra Haderslev og Åbenrå dukkede dog ikke op, og Krüger mødte heller ikke. ${ }^{17}$

Det centrale spørgsmål var foreningens formålsparagraf og dens fremtidige virke. Der forelå som sagt en ny situation med rygterne om Tillischs tilbagekaldelse. Andreas Christiansen havde oplysninger fra en »bestemt kilde«, vel Tillisch selv, at tilbagekaldelsen ikke stemte overens med Tillischs egen opfattelse, men var sket på kongens forlangende - han ønskede at få sin kære kabinetssekretær igen og at regeringen havde benyttet dette til at komme til at anvende Tillischs kraft, idet der bagved lå intriger fra Scheeles side. ${ }^{18}$ Tillischs egen holdning i sporgsmålet var nu nok en anden end den, Christiansen kunne oplyse om. Realiteten bag ved sagen var, at kongen og regeringen overtog magten fra Tillisch som overordentlig regeringskommissær. Tillisch blev i stedet udnævnt til minister for Slesvig, en udnævnelse, der fandt sted den 5. marts 1851, dagen efter generalforsamlingen. ${ }^{19}$

De delegerede besluttede derfor at lade foreningerne træde i virksomhed igen, i overensstemmelse med overdirektionens opfattelse, men med en ny formålsparagraf, da den gamle fortrinsvis havde været beregnet på tiden under bestyrelseskommissionen. Man erklærede nu at ville arbejde for den tættest mulige tilslutning til det ovrige Danmark og for en fuldstændig adskillelse fra Holsten. Formålsparagraffen var altså nærmest blevet noget skærpet, idet separationen skulle være fuldstændig.

På selve mødet anvendtes tysk nok som det overvejende forhand- 
lingssprog for foreningen, hvad der har irriteret nogle nordslesvigere. Mødet besluttede derfor, at alle fremtidige skrivelser til de dansksprogede filialforeninger skulle affattes på dansk. ${ }^{20}$ At tysk kun af praktiske grunde var blevet anvendt som forhandlingssprog af den korresponderende direktør Andreas Christiansen, kan ikke betvivles. Han havde flere gange $\mathrm{i}$ foreningens historie opfordret nordslesvigerne til at bruge dansk. Haderslev og Åbenrå foreningerne havde gjort det, men foreningen for Gråsten og omegn kun fra tid til anden. ${ }^{21}$

Af andre organisatoriske problemer på mødet var, at filialforeningerne hidtil havde handlet for selvstændigt $\mathrm{i}$ den Slesvigske Forenings navn. I fremtiden måtte deres adresser kun indsendes gennem overdirektionen. Derved styrkedes overdirektionen, der desuden skulle effektiviseres ved en nedskæring af antallet af direktører til tre, som skulle vælges af samtlige filialforeninger. Den flensborgske stamforening beholdt dog den afgørende indflydelse, idet den skulle prasentere filialforeningerne for de 6 kandidater til valg af overdirektion. Indtil nyvalget skulle den gamle overdirektion fortsætte. Der tilsigtedes ved disse beslutninger en styrkelse af den Slesvigske Forening $i$ den vanskelige situation, som man formodede var ved at opstå ved Tillischs afsættelse som overordentlig regeringskommissær.

For at modvirke denne besluttede generalforsamlingen, at der skulle afsendes to adresser til kongen, underskrevet af filialforeningernes direktioner, den ene om at beholde Tillisch som regeringskommissær for Slesvig, den anden om hertugdømmets nøje forbindelse med kongeriget og storst mulige adskillelse fra det tyske forbundsland Holsten. ${ }^{22}$ Til de organisatoriske problemer føjede sig de alvorlige økonomiske. Der var et underskud i den almene kasse på 408 mark courant, som vel til dels skyldtes de vanskeligheder, der havde været med at få inddrevet det statutmæssige fælleskontingent. Forsamlingen enedes nu om at fordele underskuddet på filialforeningernes betalingsduelige medlemmer. Men derudover var der en bred utilfredshed med det almene kontingents storrelse, hvad overdirektionen havde forudset før mødet og derfor foreslået nedsat fra 8 til 6 ß halvårligt. .s $^{23}$

Reorganiseringsarbejdet var $\mathrm{i}$ forgrunden på dette møde. Dr. Levin var villig til at starte en filialforening i Logumkloster og udarbejde en ny organisationsplan. Få dage senere fremkom han med et for- 
slag til en enklere og billigere plan, efter hvilken der kun skulle være én formand og ikke en hel direktion for de små foreninger. Dette forslag ses dog ikke at være blevet gennemført. Dr. Matthiesen fra den Danske Forening for Als og Sundeved var villig til at forelagge sin forening den i sin tid planlagte status, hvad der vist skal forstås som en fast forbindelse. ${ }^{24} \mathrm{Og}$ den flensborgske stamforening tog sig på at udarbejde nye statutter ud fra de nævnte hovedpunkter. Resultatet af dens arbejde mindede ganske betydeligt om de tidlige almene statutter, men var mere detaljerede, f. eks. vedr. stemmeforholdet mellem foreningerne indbyrdes. Forslaget til nye statutter blev dog nxppe nogensinde godkendt af filialforeningerne og derefter trykt. Den flensborgske lokalforening var for øvrigt selv i støbeskeen, idet en kommission var nedsat til at formulere nye specialstatutter for den. Det væsentlige i disse nye statutter bestod deri, at den flensborgske forening blev en filialforening på linje (næsten) med de andre og med sin egen lokale direktion, som i udelukkende flensborgske spørgsmål var uafhængig af overdirektionen. Denne nye ordning, hvorefter overdirektionen ikke længere havde en dobbeltstilling som direktion for den flensborgske stamforening og overdirektion for alle filialforeningerne, må have været en lettelse for alle parter. Som et tegn på, at det var en ændring i mere demokratisk retning, kan desuden nævnes, at foreningens specialstatutter nu åbnede mulighed for at holde månedlige medlemsmøder med politisk diskussion..$^{25}$

I lobet af marts 1851 afholdt foreningen nyvalg til overdirektion efter de ny bestemmelser, som var blevet foreslået på generalforsamlingen den 4. marts. Stamforeningen præsenterede broskriver Christian Hansen jr., købmand Erich Hansen, redaktør af Flensburger Zeitung (som havde aflest Flensburger Correspondent) dr. Claus Manicus, stenhuggermester Klewing, købmand Neuffert og hjulmager Kruse som kandidater. Ved at oplyse, hvem den flensborgske filialforening havde foretrukket, og opfordre de andre filialforeninger til at gøre valget så enkelt som muligt lagde den gamle overdirektion et vist pres på de andre filialforeninger. Den ny overdirektion bestående af Chr. Hansen jr., Erich Hansen og Claus Manicus blev da også valgt næsten enstemmigt af foreningerne i Skovsende, Bov, Tinglev, Gråsten, Østangel og Flensborg. Felsted havde ikke villet vælge, Ảbenrå og Haderslev havde ikke svaret - overdirektionen formodede, at de helt ville forlade den Slesvigske Forening. Med hensyn 
til Sønderborg og Løgumkloster var det uvist. Under sådanne vanskelige forhold var de to af de nyvalgte direktører, Erich Hansen og Chr. Hansen jr. ikke villige til at tage imod valget, medmindre to medlemmer af den gamle overdirektion fortsatte over i den ny. Det viste sig, at Andreas Christiansen og Hans Jensen var villige dertil. Manicus, en gammel veteran i den dansk-slesvigske sag fra 1838, indtog så forsædet $\mathrm{i}$ overdirektionen sammen med Christiansen. ${ }^{26}$

Det første og vigtigste problem var at sikre sammenholdet $i$ foreningen. Det lykkedes endda Manicus i første omgang at få oprettet en ny lille filialforening i Lille Solt syd for Flensborg. ${ }^{27}$ Hovedproblemet var imidlertid de nordlige foreninger.

Umiddelbart efter generalforsamlingen i marts 1851 havde Christiansen skrevet smigrende til foreningerne i Haderslev og Åbenrå om vigtigheden af en forbindelse til Nordslesvig, for sydpå trængte man til den livligere patriotisme og mere vågne følelse for nationalitet og borgerlig frihed, som fandtes nordpå. Men uden en statutmæssig forbindelse ville heller ikke Nordslesvig kunne udrette noget gavnligt, da Flensborg som hertugdømmets midtpunkt og regeringens sæde (også for det Slesvigske Ministerium) lettere og tidligere ville skaffe oplysninger om lurende farer og som centralt organ også lettere kunne bekæmpe en eventuel uenighed inden for de loyale slesvigeres egne rækker. ${ }^{28}$

Hadersleverne og åbenråerne holdt sig dog for sig selv, og den ny overdirektion måtte gøre en særlig indsats for at få forbindelse med dem igen. Overdirektionen besluttede sig derfor til at gå ind på Haderslevs gamle krav om en langt mere uforpligtende forbindelse. I et brev den 21. maj 1851 konstaterede overdirektionen med beklagelse, at der nu kun fandtes et samarbejde mellem 5 eller 6 filialforeninger i nærheden af Flensborg. Årsagen til denne opløsning så den korresponderende direktør Manicus dels $i$, at de gamle statutter havde pålagt filialforeningerne for megen tvang, dels $i$ at der nordpå fandtes mindre trang til at slutte sig sammen $i$ et fælles modparti. Den sidste begrundelse dækker nok snarest over, at nordslesvigerne ikke syntes, at slesvigholstenerne dér længere var noget stort problem. Men den anden årsag var den vigtigste, for overdirektionen skitserede nu nogle principper, hvorefter kontakt mellem overdirektionen og filialforeningerne kunne foregå. Filialforeningerne skulle stå ganske frit til at følge deres egne lokalstatutter og være uden forpligtelse til at 
yde pengebidrag til overdirektionen. Dennes opgave skulle være formidlende, kommunikere efterretninger og indlede fælles skridt. Der skulle ikke være forpligtelser i dette samarbejde udover dem, der fulgte af målet, nemlig Slesvigs fremgang og udvikling med Danmark. ${ }^{29}$ Dette tilbud bifaldt foreningen i Haderslev ganske; men den pointerede, at den havde kunnet og fremdeles ville bestå uden bidrag til fællesforeningen. ${ }^{30}$ Også den flensborgske filialforening var enig i disse principper om et løst samarbejde, som afløste generalforsamlingens forslag til nye almene statutter, men stod i ovrigt ikke så hårdt på det okonomiske. ${ }^{31}$ Hvordan Frederiksklubben stillede sig til dette forslag, kan vi desværre ikke se; men vi kan konstatere, at hverken Haderslev eller Åbenrå foreningen opløste forbindelsen til overdirektionen.

Filialforeningen i Felsted ville opløse forbindelsen til overdirektionen på grund af dennes brug af tysk sprog $i$ korrespondancen og statutterne. Dette beklagede overdirektionen meget og argumenterede udførligt for den fortsatte beståen af en forbindelse. Det var kun af praktiske grunde, at tysk havde været anvendt hidtil. Det danske sprogs udbredelse stemte tværtimod overens med overdirektionens principper, og man ville nu anvende det $i$ korrespondance og forhandlinger med de dansksprogede filialforeninger. ${ }^{32}$ Også denne forening lykkedes det at holde inden for samvirket.

Den største enkeltforening, filialforeningen i Gråsten og omegn, gik derimod bevidst sine egne veje. Dens trusel om afbrydelse af forbindelsen med overdirektionen $\mathrm{i}$ efteråret var kun gemt, ikke glemt. I foråret 1851 udarbejdede den nye statutter for foreningen, hvis navn blev Den Danske Forening for Gråsten og Omegn. Disse blev vedtaget på generalforsamlingen den 11. maj 1851 sammen med beslutningen om at træde ud af den Slesvigske Forening. Dette var på sin vis overraskende, fordi den ny forenings formålsparagraf svarede nøje til den Slesvigske Forening. Men $\$ 2$ bestemte, at sproget udelukkende var dansk, og sammenholdt med foreningens navnexndring tyder det på, at en mere bevidst dansk holdning $\mathrm{i}$ foreningen havde forårsaget udmeldelsen. Kort efter havde foreningen ikke mere kontakt med overdirektionen i Flensborg. ${ }^{33}$

Det lykkedes således at begrænse opløsningen af den Slesvigske Forening til en enkelt filialforenings udtræden; men meget liv i fællesforeningen var der ikke længere. Tillischs fjernelse som slesvigsk 
minister efter udenlandsk pres kom så overraskende for den, så den ikke formåede at stille noget effektivt op. ${ }^{34}$

Inden for den Slesvigske Forening vidste man i efteråret 1851, at det nu bar $\mathrm{i}$ retning af den konservative helstatspolitik. I oktober 1851 foretog de slesvigske og danske foreninger $\mathrm{i}$ hertugdømmet deres vel nok sidste indsats for at gøre opmærksom på deres og den loyale befolknings onsker. Initiativet udgik fra den Danske Forening for Als og Sundeved, der i et foreningsmede havde vedtaget, at der burde afsendes foreningsrepræsentanter til kongen for at bede ham $n u$ at opfylde løftet $\mathrm{i}$ proklamationen af 27 . marts 1848 om at lade indkalde deputerede fra Slesvig til den danske rigsdag. Baggrunden herfor var den udenlandske reaktions bestræbelser på at få indført provinsialstænder i Slesvig som i tiden før 1848. Dette kunne kun være en fordel for slesvig-holstenerne. ${ }^{35}$

Den flensborgske filialforening ville kun afsende en repræsentant, hvis de andre foreninger også stillede repræsentanter, i alt 3 eller 4, ellers ville den sende en deputation. ${ }^{36}$ Ingen af de andre filialforeninger ville stille en sådan repræsentant, flere, fordi det var for dyrt. ${ }^{37}$ Det blev altså det alternative middel, adresserne igen, som i november 1851 vist samlede ca. 1160 underskrifter på en kortfattet protest til Rigsdagen mod, at stormagterne ville fremtvinge genindførelsen af provinsialstænderne. ${ }^{38}$ Skau fik overdraget at overrække Rigsdagen denne henvendelse. ${ }^{39}$

Det var selvfølgelig forgæves. Helstatspolitikken trængte mere og mere frem og blev ved ministerskiftet $\mathrm{i}$ januar 1852 fastslået med Januarkundgørelsen. Det ligger for at antage, at denne kundgørelse har givet den Slesvigske Forening et chok af samme art, som ramte den tidligere gråstenske filialforening. Efter kundgørelsen overvejede denne at opløse sig, men resignerede og besluttede at ville nøjes med at være et samlingssted for de loyale og støtte regeringen imod dens fjender. M. A. Jürgensen fratrådte måneden efter, vel sagten $i$ protest. ${ }^{40} \mathrm{Om}$ både Harmonien i Haderslev og Frederiksklubben i Åbenrå ved vi, at de blev udelukkende selskabelige danske foreninger. ${ }^{11}$ Det synes at være en parallel udvikling.

Den 7. april 1852, omtrent samtidig med diskussionen $i$ den tidligere gråstenske filialforening om den skulle opløses, bad den flensborgske lokalforening overdirektionen om et møde snarest muligt for at diskutere den så of te ønskede opløsning af foreningen. ${ }^{42}$ Det 
vides ikke, om det skete på det tidspunkt; men det er vel sandsynligt.

\section{Konklusion}

Den Slesvigske Forening var de dansksindede slesvigeres første politiske parti med kompliceret foreningsopbygning, medlemskontingent, blad, representanter på Rigsdagen o. s. v. Det var en sammenslutning af alle anti-slesvigholstenske krefter. Blandt disse var de gamle danske ledere fra før 1848; men de indtog ikke en førende position i foreningen. Hovedmængden af medlemmerne var loyale slesvigere af middelklasse, som af det slesvig-holstenske oprør og dets følger var blevet tvunget til at tage parti. Foreningen startedes udfra to hensyn, dels at bevare Nordslesvigs danske sxerpreg dels at genskabe loyaliteten i den sydlige del; men det sidste blev det overvejende. Den politiske opfattelse var liberal, bortset fra foreningen i Angel, som var konservativ. Foreningens politik gik ud på en afsondring af Holsten og en nøje tilknytning af Slesvig til kongeriget. I sin politik lå foreningen nøje op ad regeringen og arbejdede tret sammen med den. Under bestyrelseskommissionen, hvor styret af Slesvig endnu ikke var helt dansk og slesvig-holstenismen endnu ikke helt fjernet, var der sammenhold $i$ foreningen. Men efter freden juli 1850 svandt sammenholdet, og de indbyrdes modsætninger mellem de dansk- og tysksprogede foreninger blev tydeligere. Alligevel lykkedes det at holde sammen på størstedelen af foreningen, indtil vel kursændringen $i$ den danske regering $i$ januar 1852 fratog medlemmerne håbet om opfyldelse af deres politiske mål.

\section{UTRYKTE KILDER}

Rigsarkivet, Kobenhavn:

Statssekretariatet (Premierministerens og statsrådets sekr.) Journalsager 1849, 1850 og 1851. Forkortet: Conseilspres. og journalnummer.

Slesvigske Ministerium 1. departement A og B. Pressesager XXXIV pk. 83. Slesvigske Ministerium 3. departement. nr. 141 a og b. Akten der dänischschleswigschen Landesregiering (Flensborg provsti).

Andreas Christiansens privatarkiv. Kopibog 1849-51. Forkortelse: Kopibog med tilfrjet dato og modtager.

T. A. J. Regensburgs privatarkiv (forkortet privark). Afskrifter, excerpter og optegnelser m. m. vedk. politiske forhold i Slesvig 1848-50.

F. F. Tillischs privatarkiv (forkortet privark). Med specifikation af læg. 
Tillischs konceptbog $\mathrm{A} i$ dette privatarkiv var udlånt og har derfor ikke kunnet benyttes til undersøgelsen.

Landsarkivet for de sønderjyske landsdele, Abenrå:

Emmerlev sognekrønike bd. I 1855-64.

Frederiksklubbens arkiv. Forhandlingsprotokol 1848-63.

Den Slesvigske Forening for Gråsten og omegn. Forhandlingsprotokol 1849-52, Statutter, medlemslister, korrespondence m. m. 1849-52. Forkortet Sl.F.f.Gr. med tilføjelsen forhandlingsprotokol eller $p k$.

Stadtarchiv Flensburg (forkortet StA):

A862 fasc. 2 Innere Unruhen und Aufruhr ... 1851-65.

Det Kongelige Bibliotek, København:

Claus Manicus, brev nr. 910 til P. C. Koch, Ny Kgl., Samling 1763 fol.

\section{TRYKTE KILDER}

Adress-Buch der Stadt Flensburg 1847.

Chronologisk Samling af de i Aarene 1848, 1849 og 1850 udkomne Love. Dannevirke aug.-sept. 1849.

Flensburger Correspondent (senere Flensburger Zeitung) 1849-1850.

L. Skaus brevveksling med politiske venner i Senderjylland I (1970) Udg. af $\mathrm{H}$. V. Gregersen.

Statsrådets forhandlinger bd. 2 (1956). Udg. ved Harald Jørgensen.

\section{Fremstillinger:}

Kristian Carøe: Den danske Lxgestand. Supplementsbind til 7. udg. (1904). Danmarks Riges Historie bd. VI 1814-64 af A. D. Jørgensen og N. Neergaard.

Jens Engberg: Det slesvigske spørgsmål 1850-53. (1968).

A. Falk-Jensen og H. Hjorth-Nielsen: Candidati og examinati juris 17361936, candidati politices 1852-1936 og candidati actuarii 1922-1936. bd. I (1954).

Flensborg Bys Historie bd. 2. (1955). Red. af Johan Hvidtfeldt, Holger Hjelholt og Knud Kretzschmer.

Hans Vald. Gregersen: Fra den nationale vækkelse i landsognene omkring Abenrå. I S Jy Årb 1951.

Ludvig Hertel: Hans Wilhelm Hertel. Bidrag til den sønderjydske Folkevækkelses Historie (Odense 1897).

Holger Hjelholt: Den danske Sprogordning og det danske Sprogstyre i Slesvig mellem Krigene 1850-1864 (1923).

Holger Hjelholt: Sønderjylland under Treårskrigen bd. 2 (1961).

H. R. Hiort-Lorenzen: Den slesvigske Forening. I SJy Arb 1890.

G. Japsen: Den nationale udvikling i Ảbenrå 1800-1850 (1961). 
G. Japsen: Betragtninger over den danske bevægelse i Nordslesvig. I SJy Arb 1973.

(A. D. Jørgensen): Adolf Ditlev Jørgensen og hustru Ida Marie Pedersens Slægtebog. 24. Marts 1894. Trykt som manuskript.

A. D. Jørgensen: En Redegørelse for min Udvikling og mit Forfatterskab (1901).

Elisabeth Kardel: Die Stadt Flensburg und die politischen und nationalen Zeitströmungen um die Mitte des 19. Jahrhunderts (Flensburg 1929). P. Lauridsen: Mellem Slagene. I S Jy Årb 1899 og 1900.

H. F. Petersen: A. Regenburg og Senderjylland. I SJy Årb 1936.

Dieter Pust: Politische Sozialgeschichte der Stadt Flensburg. Diss. Manuskript (1973).

L. S. Ravn: Lxrerne under sprogreskripterne (Flensborg 1971).

Sønderjyllands Historie fremstillet for det danske Folk bd. IV. 1805-64. Af Knud Fabricius.

E. Vedel: Den slesvigske Privatrets almindelige Deel (1857).

Jørgen Witte: Myndighedernes forhold til de dansksindede blade $\mathrm{i}$ hertugdømmet Slesvig før 1848. Manuskript 1973.

Ảbenrå Bys Historie bd. 2 (1967). Red. af Johan Hvidtfeldt og Peter Kr. Iversen.

1. op.cit. s. 437.

\section{NOTER}

Indledning

2. i SJy Arb 1900 s. 80 f.

3. op. cit. s. 96 ff., 120.

4. H. R. Hiort-Lorenzen: Den slesvigske Forening. I SJy Arb 1890 s. $120 \mathrm{ff}$.

5. Sønderjyllands Historie bd. IV s. $388 \mathrm{f}$. Hjelholt: Sønderjylland under Treårskrigen bd. 2 s. $166 \mathrm{f}$.

6. Japsen: Den nationale udvikling s. 234.

7. Sønderjyllands Historie bd. IV s. 340-396. Hjelholt: Sønderjylland under Treårskrigen bd. II s. $237 \mathrm{f}$.

8. Japsen: Den nationale udvikling s. 51, for Ảbenrås vedkommende. Japsen: Betragtninger over den danske bevægelse i Nordslesvig.

9. Japsen: Den nationale udvikling passim. Japsen: Betragtninger s. 66.

10. Flensborg Bys Historie bd. II s. $127 \mathrm{ff}$ og 201. Kardel s. 28.

11. Sønderjyllands Historie bd. IV s. $370 \mathrm{f}$.

\section{Foreningens dannelse}

1. Tillischs privark. B 1. petition af $15 / 6-49$.

2. Tillischs privark. B 3. Udtog af de Mezas andragende til A. W. Moltke 22/9-49.

3. Hjelholt: Sønderjylland under Treårskrigen bd. 2 s. 59.

4. Flensborg Bys Historie bd. 2 s. 187 f. Lauridsen: Mellem Slagene. I SJy Arb 1899 s. $210 \mathrm{f}$.

5. Dannevirke 31/8-49 og 3/9-49.

6. Sl.F.f.Gr., pk, Specialstatutter for den flensborgske stamforening 1849. 
7. Chronologisk Samling af de i Aarene 1848, 1849 og 1850 udkomne Love s. LVI $f$.

8. Kopibog 13/9-49 - Fischer.

9. Sl.F.f.Gr., pk, Specialstatutter for den flensborgske stamforening 1849. Sl.F.f.Gr., pk, *Wahlact auf der Compagnie und Bemerkung der verschiedenen Sitzungen « udat. Optællingen af stemmerne viser, at agent Jensen $i$ de tre valgomgange fik flest, 158 stemmer, Jordt 120, Neuffert 120, Levestamm 93, Chr. Hansen jr. 78, Fessel 83, Erich Hansen 75, Overbeck 68, Struckmann 53, Sibbers 70 stemmer. Deres profession er angivet efter Adress-Buch 1847.

10. Sl.F.f.Gr., pk, skrivelse fra bestyrelseskommissionen til overdirektionen 19/9-49.

11. E. Vedel: Den slesvigske Privatrets almindelige Deel, s. $211 \mathrm{ff}$.

12. H. F. Petersen: Regenburg og Senderjylland s. 21. Tillischs privark. B 3. Udtog af de Mezas andragende til A. W. Moltke 22/9-49.

13. Conseilspræs. 92/49, Tillisch-Moltke 15/8-49. Tillischs privark. B 1 MoltkeTillisch 20/8-49.

14. Conseilspræs. 110/49, Tillisch-Moltke 30/8-49. Statsrådets forhandlinger bd. 2 s. $225 \mathrm{f}$.

15. Tillischs privark. B 3. Udtog af de Mezas andragende til A. W. Moltke 22/9-49.

16. Sl.F.f.Gr., pk, skrivelse fra bestyrelseskommissionen til overdirektionen $19 / 9-49$.

17. Witte s. $17 \mathrm{ff}$.

18. Tillischs privark. D 2, Slesvigske Forening-bestyrelseskommissionen 21/9-49.

19. Witte s. 187. Tillischs privark. B 20. Sponneck-Tillisch 31/8-49.

20. Tillischs privark. B 20. Sponneck-Tillisch 10/9-49 og 17/9-49.

21. Tillischs privark. B 20. Sponneck-Tillisch 27/6-50.

22. Slesv. Min. 1. dep. A og B, Pressesager XXXIV pk. 83, Levestamms ansøgning 8/4-54.

23. Kopibog 27/9-49 - Broberg. 9/10-49 - Genzsch \& Heyse. 18/10-49 - Broberg. 1/11-49 - Broberg. Flensburger Correspondent 27/10-49 om opstilling af hurtigpressen. Kopibog 26/10-49 - Krüger.

24. Flensburger Correspondent $18 / 10-49$ og 20/10-49. Tillischs privark. D 3 . Nagel-Tillisch 18/10-49.

25. Flensburger Correspondent 21/11-49 og 15/6-50.

\section{Fallesforeningen og statutterne}

1. Frederiksklubbens ark. Forhandlingsprotokol $1848-63$ indledningen. Conseilspræs. 129/49 Frederiksklubben-statsrådet 12/12-49.

2. Kopibog 13/9-49 - Fischer.

3. Kopibog 26/10-49 - Krüger. 27/10-49 lederne i Haderslev. Skaus brevveksling med politiske venner i Sønderjylland bd. I s. 202.

4. Harmonien 1799-1849-1949, s. 96-106. Oplysning fra adjunkt Henrik Fangel om foreningens første møde.

5. Kopibog 27/10-49 - lederne i Haderslev.

6. Kopibog 27/10-49 - lederne i Haderslev. Sl.F.f.Gr., pk, overdirektionen farver Jürgensen 19/11-49.

7. Kopibog 27/10-49 - lederne i Haderslev. Skaus brevveksling med politiske venner $\mathrm{i}$ Sønderjylland bd. I s. 202. 
8. Sl.F.f.Gr., pk, Almene statutter 1849.

9. Kopibog 19/11-49 - Haderslev.

10. Kopibog 8/11-49 - Ảbenrå. 22/11-49 - Fischer. 22/11-49 - Haderslev.

11. Jvf. ovenfor s. 91 og 95 f.

12. Sl.F.f.Gr., pk, Almene statutter $1849 \$ 13$.

13. Sl.F.f.Gr., pk, flensborgske specialstatutter 1849.

14. Frederiksklubbens ark. Forhandlingsprotokol 1848-63, indledning.

15. Harmonien 1799-1849-1949, s. 99.

16. Sl.F.f.Gr., forhandlingsprotokol $8 / 2-50$.

\section{Udbredelsen af andre filialforeninger}

1. Kopibog 19/11-49 - Haderslev.

2. Kopibog 22/11-49 - P. Nissen. Gregersen: Fra den nationale vakkelse i landsognene omkring Ảbenrå s. 188. Ravn: Lærerne under sprogreskripterne, s. 233. Kopibog 23/11-49 - Refslund.

3. Hjelholt: Sønderjylland under Treårskrigen bd. 2 s. 192. Kopibog 19/11-49 Fischer.

4. Kopibog 19/11-49 - Jürgensen.

5. Kopibog 4/12-49 - Jürgensen. 14/12-49 - Jürgensen.

6. Kopibog 27/11-49 - Jürgensen.

7. Sl.F.f.Gr., pk, direktionen i Gråsten til hjulmager Jürgensen 31/12-49.

8. Sl.F.f.Gr., forhandlingsprotokol $28 / 12-49$.

9. Sl.F.f.Gr., forhandlingsprotokol 8/2-50. Sl.F.f.Gr., pk, den gråstenske filialforening - hjulmager Jürgensen i Sottrup 4/2-50.

10. Sl.F.f.Gr., forhandlingsprotokol 28/12-49.

11. Hjelholt: Sonderjylland under Treårskrigen bd. II s. $115 \mathrm{f}$.

12. Slesv. Min., 3. dep. nr. 141 a., Vollertsen til bestyrelseskommissionen 6/9-49.

13. Hjelholt: Sønderjylland under Treårskrigen bd. II s. $244 \mathrm{f}$.

14. Slesv. Min., 3. dep. nr. 141 b., skrivelser 10/4-50 og 27/6-50 til bestyrelseskommissionen.

15. Slesv. Min., 3. dep. nr. 141 a., skrivelse 2/4-50 til bestyrelseskommissionen.

16. Sl.F.f.Gr., pk, Programm des Schlesw. Vereins in Ostangeln « december 1849, kopi.

17. Kopibog 22/12-49 - Skau.

18. Sl.F.f.Gr., pk, Actum Steinberghaff 13/1-50 og 20/1-50. Kopibog 22/1-50 Martens-overdirektionen, kopi.

19. Conseilspres. 3/49, adresse 6/1-49.

20. Slesv. Min., 3. dep. nr. 141 b., Bov primo april 1850. Hjelholt, Sønderjylland under Treårskrigen bd. II s. 243.

21. Kopibog 21/4-50 - Jürgensen. Sl.F.f.Gr., pk, Bov-overdirektion 22/4-51 og 21/11-51. Ravn, Lærerne under sprogreskripterne s. 159 og 164.

22. Sl.F.f.Gr., pk, Skovsende-overdirektionen 27/4-50.

23. Kopibog 1/5-50 - Skovsende.

24. Sl.F.f.Gr., pk, Skovsende-overdirektionen 2/10-51., pk, udat. fortegnelse over direktionsmedlemmer. Kopibog 2/7-50 - Sternhagen.

25. Sl.F.f.Gr., Andreas Christiansen - overdirektion 24/12-50. Candidati og examinati juris bd. I s. $221 \mathrm{f}$. Frederiksklubbens ark., forhandlingsprotokol medlemsliste nr. 149.

27. Kopibog 23/5-50 - Sørensen.

28. Kopibog 17/6-50 - Bov. 14/6-50 - Sørensen. 
29. Kopibog 23/11-49 - Schmidt.

30. Kopibog 28/5-50 - Tinglev.

31. Kopibog 19/10-50 - Felsted.

32. Kopibog udat., ca. juni 1850 - Angel.

33. Sl.F.f.Gr., pk, C. Manicus - J. O. Nissen 15/5-51. Ravn: Lareme under sprogreskripterne s. 232. Sl.F.f.Gr., forhandlingsprotokol 25/5-51.

34. Kopibog 16/3-50 - Schmidt. 17/3-50 - Christiansen. 17/3-50 - Jürgensen. Om S. P. Levin, se K. Carøe: Den danske Lxgestand. Supplementsbind til 7. udg. s. 65.

35. Flensburger Correspondent 20/11-49.

36. Kopibog 20/6-50 - Nagel. 5/7-50 - Nagel.

37. Emmerlev sognekronike $1855-64$, bd. I s. 216 f.

38. Kopibog 18/3-50 - Matthiesen. Om dr. Matthiesen, se K. Carøe: Den danske Lxgestand. Supplementsbind til 7. udg. s. 70.

39. Kopibog 26/3-50 - Matthiesen.

40. Som et eksempel kan nævnes, at det er Andreas Christiansen, som sender den nævnte adresse fra Als til statsrådet, se Conseilspræs. 37/50, Christiansen A. W. Moltke udat. SI.F.f.Gr., pk, protokolekstrakt 4/3-51. Kopibog 31/3-51 - Danske Forening for Als og Sundeved.

\section{Medlemstal og sociale tilhorsforbold}

1. Se nedenfor s. 118 .

2. Kopibog 18/3-50 - Matthiesen.

3. Kopibog $17 / 6-50$ - Bov.

4. Sl.F.f.Gr., pk, skifte i overdirektion 4/5-51. Her er tilføjet, at tallet for Stenbjerg skal være 160 ifølge en adresse til kongen, i stedet for de angivne 54. Tallet 54 dækker åbenbart de medlemmer, hvis navne er blevet oplyst overfor overdirektionen.

5. Kopibog 6/7-50 - Clausen.

6. Se ovenfor s. 91.

7. Dieter Pust: Politische Sozialgeschichte der Stadt Flensburg, manuskript s. 212.

8. Overdirektionen bestod derefter af lage Claus Manicus, broskriver Christian Hansen jr., købmand Andreas Christiansen jr., købmand Erich Hansen og farver Hans Jensen. Den ny flensborgske direktion erstattede timandsudvalget og bestod kun af fem personer: fabrikant Neuffert, stenhuggermester Klewing, murermester Herold, hjulmager Joh. H. Kruse, skipper Hans Bladt. I Fl.StA A 862 fasc. 2 nr. 6 er der en skrivelse fra den flensborgske lokaldirektion underskrevet af de nævinte personer.

9. Fl. StA A 862 fasc. 2 nr. 15 udat. petition.

10. Flensburger Correspondent 15/6-50.

11. Flensburger Correspondent $7 / 9-50$.

12. Frederiksklubbens ark, forhandlingsprotokol 1848-63. Japsen: Den nationale udvikling s. 248. Kopibog 18/3-50-Matthiesen.

13. Oplysning fra adjunkt Henrik Fangel om Harmoniens medlemmer.

14. Sl.F.f.Gr., pk, Udat. liste over direktionsmedlemmer, fra foråret 1851.

15. Sl.F.f.Gr., pk, Udat. navnefortegnelse fra foreningen i Skovsende, fra foråret 1850.

16. Sl.F.f.Gr., pk, Skovsende-overdirektionen 27/10-51.

17. SI.F.f.Gr., forhandlingsprotokol $28 / 12-49$. 
18. Sl.F.f.Gr., forhandlingsprotokol 8/2-50. Hertil kom vist også hjulmager Jürgensen i Sottrup, se SI.F.f.Gr, pk, brev 4/2-50 fra direktionen i Gråsten hjulmager Jürgensen.

19. Problemet er her som ved petitionen fra Flensborg, at fornavnet tit kun er angivet med forbogstavet, hvorved identifikationen vanskeliggeres. Til rådighed for en sådan undersøgelse er der for den gråstenske filialforenings vedkommende en fyldig medlemsprotokol. A. D. Jørgensen: En redegørelse. s. 16.

20. Sl.F.f.Gr., pk, udat. fortegnelse over direktionsmedlemmer fra foråret 1851.

\section{Foreningens okonomi}

1. Bestemmelsen findes allerede kopibog 27/10-49. Sl.F.f.Gr., læg Statutter, A1mene statutter 1849 \&9.

2. Kopibog 8/7-50-E. Hansen.

3. Kopibog 29/8-50 - Gråsten.

4. Kopibog 30/8-50 - Åbenrå.

5. Kopibog 30/8-50 - Skovsende.

6. Kopibog 30/8-50 - Angel.

7. Kopibog 6/7-50- Haderslev.

8. Kopibog 29/8-50-Haderslev.

9. Sl.F.f.Gr., pk, Haderslev-overdirektionen 23/5-51.

10. Kopibog 14/6-50 - Sørensen.

11. Kopibog 6/7-50 - Sørensen.

12. Kopibog 24/12-50 - Tinglev. 24/12-50 - Aller.

13. Kopibog, bagerst på blad 35.

14. Kopibog 31/3-51 - Tinglev.

15. Kopibog 29/8-50-Gråsten.

16. Kopibog 29/8-50 - Haderslev.

17. SI.F.f.Gr., pk, skifte i overdirektionen $4 / 5-51$.

\section{Foreningens politik}

1. Hjelholt: Sønderjylland under Treårskrigen bd. II s. 169. Slesv. Min., 3. dep. nr. 141 a.

2. Lauridsen: Mellem Slagene i SJy Årb 1900 s. 80 f. Tillischs privark. D 2, Slesvigske Forening - Tillisch 2/1-50 med bilag. Betegnelsen for den haderslevske filialforening som DDen slesvigske patriotiske Forening * hos Lauridsen er ukorrekt.

3. Kopibog adskillige breve. Flensburger Correspondent med omtale af aktiviteterne i mange numre.

4. De dekoreredes for dette $\mathrm{i}$ april 1851. Det drejer sig især om agentinde Christiansen, Cathrine Christiansen, Johanne Schmidt, Emma Ingwersen. Se 'Tillischs privark. C 1, Frederik 7. - Tillisch 29/4-51.

5. Kopibog 2/7-50 - E. Clausen. 2/7-50 - Sternhagen.

6. Kopibog udat. koncept til petition ca. 19/11-49. 20/11-49 - Koch. 20/11-49 Fischer.

7. Kopibog 22/11-49 - Schmidt. 23/11-49 - Fischer.

8. Regensburgs privark. Afskrifter, excerpter og optegnelser $\mathrm{m}$. $\mathrm{m}$. vedk. politiske forhold i Slesvig 1848-50. Tillisch - A. W. Moltke 21/11-49 i afskrift.

9. Kopibog 23/11-49 - Fischer. 
10. Conseilspræs. $129 / 49$, adresse $9 / 12-49$.

11. Kopibog 11/12-49 - Fischer. 23/11-49 - Schmidt. Conseilspres. 129/49, Frederiksklubben - statsrådet 12/12-49. Kopibog 4/1-50 - Gråsten. Conseilspras. 35/50, overdirektion - A. W. Moltke 24/1-50.

12. Conseilspræs. $129 / 49$, adresse med statsrådssekretærens bemærkninger 20/12-49.

13. Flensburger Correspondent 16/3-50.

14. Kopibog 23/11-49 - Fischer. 19/11-49 - Fischer.

15. Kopibog 4/12-49 - Fischer.

16. Kopibog 8/12-49 - Jürgensen.

17. Kopibog 21/12-49 - Fischer.

18. Kopibog 25/12-49 - Schmidt. 8/1-50 - Skau.

19. Kopibog 30/1-50 - Koch. Flensburger Correspondent 16/3-50. Det af vigende tal underskrifter fra det almindeligt opgivne, skyldes en regnefejl $i$ datiden. Se Sl.F.f.Gr., pk, udat. optzlling af stemmer. Hjelholt: Sønderjylland under Treårskrigen bd. II s. 230.

20. Tillischs privark. D 3, Levestamm-Tillisch 12/2-50.

21. Statsrådets forhandlinger bd. 2 s. 390 . Flensburger Correspondent 16/3-50.

22. Tillischs privark. D 3, Levestamm-Tillisch 12/2-50.

23. Denne henvendelse formuleret af statsrådet og Tillisch har Hjelholt opfattet som udtryk for slesvigernes følelser. Hjeltholt: Sønderjylland under Treårskrigen bd. II s. 230. Tillischs privark. B 3, Moltke-Tillisch 18/2-50, samme E, henvendelsen til Palmerston udat. Regenburgs privark., Afskrifter, excerpter og optegnelser m. m. vedk. politiske forhold i Slesvig 1848-50, afskrift af henvendelsen.

24. Kopibog 6/3-50 - Fischer.

25. Hjelholt: Senderjylland under Treårskrigen bd. II s. 230.

26. Sl.F.f.Gr., pk, Hodges-overdirektionen 22/3-50. Flensburger Correspondent 26/3-50.

27. Conseilspræs. 22/50, A. Christiansen jr. - A. W. Moltke 25/3-50.

28. Chronologisk Samling af de i Aarene 1848, 1849 og 1850 udkomne Love s. 5 f. Hjelholt: Sønderjylland under Treårskrigen bd. II s. $78 \mathrm{f}$.

29. Conseilspræs. 35/50, takadresse fra Slesv. Foren. i Angel 21/1-50.

30. Flensburger Correspondent 18/3-50.

31. Sl.F.f.Gr., pak., Hodges-Slesv, Foren. 1/4-50. Flensburger Correspondent 6/4-50.

32. Kopibog 4/4-50 - Leisner.

33. Kopibog 21/12-49 - Fischer.

34. Kopibog 21/1-50 - Krüger.

35. Sl.F.f.Gr., pk, Refslund-Christiansen 29/1-50 med protokol over mødet 18/1-50.

36. Sl.F.f.Gr., pk, Protokollat over Haderslevmødet 20/1-50, kopi udfærdiget af E. Manicus. samme, randbemærkning på adressen til kongen om proklamationen af 27. marts 1848, dat. jan. 1850. Kopibog 23/1-50 - Broberg. 23/1-50 Knudsen. 23/1-50 - Skau.

37. Sl.F.f.Gr., pk, Christiansen-C. Manicus 20/11-51.

38. Sl.F.f.Gr., pk, petition 20/1-50 fra Haderslev.

39. Statsrådets forhandlinger bd. 2 s. 400 f. Tillischs privark. D 3, Pechlin-Tillisch 26/2-50.

40. Flensburger Correspondent 12/3-50. Hjelholt: Senderjylland under Treårskrigen. bd. II s. 218 og 229. 
41. Skipperlavets oldermand gav julen 185053 rbdl. til de sårede danske krigere og de faldnes efterladte, se Kopibog 27/12-50. Flensburger Correspondent 7/3-50. Kopibog 6/3-50-Schmidt.

42. Kopibog 8/3-50 - Krüger. 5/3-50 - Fischer. 5/3-50 - Haderslev. 8/3-50 Schmidt.

43. Sl.F.f.Gr., forhandlingsprotokol, udat. henvendelse til Pechlin. Conseilspras. 41/50, adresse 7/4-50 fra Slesv. Foren. i Angel. Flensburger Correspondent 11/4-50. Kopibog 26/3-50 - Matthiesen.

44. SI.F.f.Gr., forhandlingsprotokol, overdirektionen - Gråsten 15/4-50.

45. Kopibog 16/4-50 - Levin. 16/4-50 - Danske Forening for Als og Sundeved. $16 / 4-50$ - Schmidt.

46. Kopibog 21/4-50 - Jürgensen. Sl.F.f.Gr., forhandlingsprotokol 15/4-50 og 17/4-50.

47. Sl.F.f.Gr., forhandlingsprotokol 18/4-50.

48. Flensburger Correspondent 4/4-50.

49. Sl.F.f.Gr., forhandlingsprotokol 23/4-50. Flensburger Correspondent 29/4-50, oversættelse efter Berl. Tidende 25/4-50.

50. Flensburger Correspondent 4/5-50. Kopibog 1/5-50 - Skovsende.

51. Kopibog $8 / 6-50$ - Fischer.

52. Kopibog 7/6-50 - Krïger. 8/6-50- Haderslev.

53. Sønderjyllands Historie bd. IV s. 413. Tillischs privark., E, brev 17/6-50 åbenbart fra Tillisch til Moltke, men i omslag »at henlægge«.

54. Engberg: Det slesvigske spørgsmål s. 19 og $78 \mathrm{f}$.

55. Statsrådets forhandlinger bd. 2 s. 488. Conseilspræs. 89/50, Tillisch-Moltke 26/7-50.

56. Tillischs privark. D 3, Levestamm-Tillisch 17/6-50.

57. Kopibog 19/6-50 - Krüger. 20/6-50 - Nagel. 20/6-50 - Levin. 19/6-50 Haderslev. 20/6-50 - Sørensen. 20/6-50 - Petersen.

58. Conseilspræs. 62/50, Christiansen-Moltke 26/6-50.

59. Kopibog 16/6-50 - Haderslev. 30/6-50 - Haderslev. 30/6-50 - Koch.

60. Sl.F.f.Gr., pk, Haderslev-overdirektion 1/7-50. Kopibog 5/7-50 - Haderslev.

61. Kopibog 6/7-50 - Sørensen.

62. Conseilspræs. 62/50, overdirektion - Moltke 6/7-50.

63. Conseilspres. 83/50, adresse fra Slesv. Foren. i Angel 6/7-50.

64. Kopibog 7/7-50 - Haderslev. 7/7-50 - Krüger. Conseilspræs. 62/50, Slesv. Foren. i Haderslev adresse 9/7-50.

65. Statsrådets forhandlinger bd. 2 s. 534 og 539.

66. Kopibog 27/8-50 - Skovsende. 29/8-50 - Danske Forening for Als og Sundeved.

67. Kopibog 29/7-50 - Jürgensen.

68. Flensburger Correspondent 27/9-50.

69. Sl.F.f.Gr., pk, Refslund-Christiansen 29/1-50.

70. Flensburger Correspondent 9/9-50.

71. Sønderjyllands Historie bd. IV s. $410 \mathrm{f}$.

72. Kopibog 22/7-50 - Jürgensen. H. F. Petersen: Regenburg og Sønderjylland. i SJy Ārb 1936 s. 21-23. Engberg: Det slesvigske spørgsmål s. $64 \mathrm{f}$.

73. Kopibog 22/7-50 - Jürgensen.

74. Kopibog 24/7-50 - Bov.

75. Flensburger Correspondent 9/9-50.

76. Efter L. Hertel: Hans Wilhelm Hertel s. 327 f. 
77. Sønderjyllands Historie bd. IV s. 419-24. Engberg: Det slesvigske spørgsmål s. $89 \mathrm{ff}$ og $133 \mathrm{ff}$.

78. Tillischs privark., B 3, Christiansen-Tillisch 24/7-50. i et andet brev anbefalede Christiansen pastor Otzen i Kværn, som nærede sådanne synspunkter, at han ville være værdig som notabel, se kopibog 27/7-50 - Tillisch.

79. Sønderjyllands Historie bd. IV s. 420 angiver fejlagtigt Andreas Christiansen jr. som medlem af notabelforsamlingen.

80. Engberg: Det slesvigske spergsmål s. 133.

81. Sønderjyllands Historie bd. IV s. 424.

82. Se nedenfor s. 136.

83. Tillischs privark., D 3, Skau-Tillisch 9/7-51.

84. Conseilspræs. 68/51., Christiansen-Moltke 8/7-51. samme Wegener-Moltke 11/7-51.

85. Conseilspræs. 71/51, overdirektionen - Moltke 12/7-51.

\section{Foreningens reorganisering og ophor}

1. Kopibog 5/7-50 - Vollertsen. 6/7-50 - Haderslev. 8/7-50 - Levin. 7/6-50 Krüger.

2. Kopibog 6/7-50 - Clausen. 7/7-50 - Paulsen.

3. Tillischs privark., B 3, A. W. Moltke-Tillisch 12/12-49.

4. Tillischs privark., B 3, A. W. Moltke-Tillisch 27/7-50 og 5/8-50. Conseilspres. $88 / 50$, indstilling fra premierministeren, dateret $26 / 7-50$, kgl. resolution 28/7-50.

5. Sl.F.f.Gr., pk, Almene statutter $1849 \$ 3 \circ 14$.

6. Flensburger Correspondent 7/9-50.

7. Kopibog 23/12-50 - Bov. 21/12-50 - Gråsten. 24/12-50 - Tinglev.

8. Sl.F.f.Gr., forhandlingsprotokol 19/11-50. Sl.F.f.Gr., pk, Gråsten-overdirektionen 24/11-50.

9. Kopibog $19 / 10-50$ - Felsted.

10. Kopibog 23/12-50 - Bov.

11. Sl.F.f.Gr., pk, Gråsten-overdirektionen 12/1-51.

12. Kopibog 10/1-51 - Skovsende. 28/1-51 - Martens. 27/1-51 - Ảbenrå. 11/2-51 - Fischer. 27/1-51 - Bov.

13. Kopibog 11/2-51 - Koch. 11/2-51 - Fischer. Dannevirke ses ikke at have bragt annoncen.

14. Kopibog 23/2-51 - Skovsende. 2/2-51 - Krüger.

15. Kopibog 23/2-51 - Skovsende.

16. Kopibog bagest side 35 .

17. Kopibog 6/3-51.6/3-51 - Ảbenrå. 7/3-51 - Krüger.

18. Kopibog 7/3-51 - Krüger.

19. Hjelholt: Den danske sprogordning og det danske sprogstyre i Slesvig mellem Krigene. s. 12. Hjelholt: Sønderjylland under Treårskrigen. bd. II s. 51 .

20. Sl.F.f.Gr., pk, protokolekstrakt 4/3-51.

21. Om en dansksproget adresse, se Kopibog 8/7-50 - Levin. Sl.F.f.Gr., pk, rummer korrespondence på begge sprog, men overvejende på tysk. Kopibog 25/4-51 - Felsted.

22. SI.F.f.Gr., pk, protokolekstrakt 4/3-51. Conseilspres. 51/51, overdirektionen Moltke 26/3-51.

23. Kopibog 11/2-51 - Koch. 11/2-51 - Fischer. 
24. Sl.F.f.Gr., pk, protokolekstrakt 4/3-51. Kopibog 11/3-51 - Levin. 31/3-51 Danske Forening for Als og Sundeved.

25. Sl.F.f.Gr., pk, specialstatutter for Flensborg 1851.

26. Sl.F.f.Gr., pk, skifte i overdirektionen 4/5-51. *Actum Flensburg* 9/5-51. Om Manicus, se Witte s. $76 \mathrm{f}$.

27. Sl.F.f.Gr, pk, C Manicus-J O. Nissen 15/5-51. Sl.F.f.Gr., forhandlingsprotokol 25/5-51.

28. Kopibog 6/3-51 - Haderslev. 6/3-51 - Åbenrå.

29. Sl.F.f.Gr., pk, Actum Flensburg* 22/5-51. Kgl. B., Claus Manicus-P. C. Koch 21/5-51 brevnr. 910.

30. Sl.F.f.Gr., pk, Haderslev-overdirektionen 23/5-51.

31. Sl.F.f.Gr., pk, "Actum Flensburg « 22/5-51.

32. Kopibog 25/4-51 - Felsted.

33. Sl.F.f.Gr., pk, Statutter for den Danske Forening for Gråsten og omegn 1851. Sl.F.f.Gr., forhandlingsprotokol 23/2-51, 11/5-51 og 25/5-51. Se også begrundelsen i A. D. Jørgensens Slægtebog s. 27 f.

34. Se ovenfor s. 132.

35. Sl.F.f.Gr., pk, Danske Forening for Als og Sundeved-overdirektionen 18/10 51. samme, Manicus' koncept på dansk og tysk til filialforeningerne, udat.

36. Sl.F.f.Gr., pk, den flensborgske lokalforening-overdirektionen 22/10-51 og 26/10-51.

37. Sl.F.f.Gr., pk, Koch - overdirektion 22/10-51. Fischer-Christiansen 25/10-51. Skovsende - overdirektionen 27/10-51. Felsted - overdirektionen 4/11-51.

38. Sl.F.f.Gr., pk, adresse november 1851.

39. Sl.F.f.Gr., pk, Christiansen-C. Manicus 20/11-51.

40. Sl.F.f.Gr., forhandlingsprotokol 9/5-52 og 6/6-52.

41. Harmonien 1799-1849-1949. s. 107 ff. Ảbenrå Bys Historie bd. 2 s. 217 f.

42. Sl.F.f.Gr., pk, flensborgske lokalforening - overdirektionen 7/4-52.

Efter sætningen af manuskriptet til denne artikel har Dansk Centralbibliotek for Sydslesvig oplyst, at forfatteren ved en beklagelig fejltagelse ikke er blevet underrettet om, at en del af arkivet fra den flensborgske afdeling af den Slesvigske Forening findes på Centralbiblioteket. I Sønderjyske Årbøger 1976 vil forfatteren derfor supplere foreningens historie på grundlag af dette arkiv. 